\title{
Construir el pueblo aprista: el diario La Tribuna en su primer año de vida*
}

\section{Building an Aprista People: The Newspaper La Tribuna in Its First Year of Existence}

\section{MARTÍN BERGEL}

Escuela de Humanidades-UNSAM / Centro de Historial Intelectual-UNQ / CONICET

bergelmartin@gmail.com

\section{RESUMEN}

Este artículo ofrece una reconstrucción minuciosa del diario aprista La Tribuna en su primer año de existencia. Desde un ángulo que atiende tanto a sus aspectos discursivos como materiales, y en diálogo con la historiografía reciente sobre la prensa periódica y la cultura impresa en América Latina, este ensayo argumenta que el vocero oficial del APRA fue un dispositivo crucial tanto en el proceso de popularización de este partido como en la propia construcción de la noción de un "pueblo aprista». La Tribuna fue un artefacto que organizó y visibilizó la vida partidaria. Pero su éxito inicial no tuvo que ver meramente con el hecho de haberse posicionado en ese rol, sino también con haberse acoplado eficazmente al proceso de modernización de la prensa periódica en el Perú.

Palabras clave: prensa periódica; populismo; aprismo; intelectuales; modernización cultural

\footnotetext{
* Un primer avance de este artículo se presentó en la mesa «Nuevas aproximaciones a la historia del aprismo en el período de entreguerras", XXXIV Congreso de LASA, Nueva York, 27 al 30 de mayo de 2016. Agradezco a Laura Ehrlich y a los evaluadores anónimos por la lectura y comentarios de esta versión final.
}

HISTORIOA XLII.1 (2018): 141-183 / ISSN 0252-8894

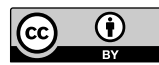




\section{ABSTRACT}

This article offers a meticulous reconstruction of the La Tribuna newspaper in its first year of existence. From a perspective that addresses both its discursive and material aspects, and in dialogue with recent historiography on the press and printed culture in Latin America, this essay argues that the official newspaper of APRA played a crucial role in the popularization of the party as well as in the very construction of the notion of an "Aprista people" ("pueblo aprista»). La Tribuna was a tool that organized and gave visibility to the life of the party. But its initial success was not merely due to the fact of having positioned itself in that role, but also to having effectively coupled itself with the process of the periodical press's modernization in Peru.

Keywords: periodical press; populism; aprismo; intellectuals; cultural modernization

$\mathrm{H}$ ace poco más de cuarenta años, en uno de los múltiples ensayos breves que engalanan su prolífica producción, Alberto Flores Galindo se preguntaba por los factores que determinaron el meteórico crecimiento en el Perú de la Alianza Popular Revolucionaria Americana (APRA) a inicios de los años $1930 .{ }^{1}$ Como es de sobra sabido, el aprismo ha sido el principal partido político de la historia peruana contemporánea, y uno de los primeros y más influyentes movimientos que abonaron la tradición populista latinoamericana. Creado desde el exilio a mediados de los años veinte por Víctor Raúl Haya de la Torre, su desarrollo en territorio peruano solo cobró vigor luego de la caída de Augusto B. Leguía en 1930, y del consecuente retorno al país de su indiscutido líder y de las jóvenes figuras que lo secundaban en el destierro. El que se ganaría el apelativo de «Partido del Pueblo» experimentó entonces un vertiginoso crecimiento, y obtuvo un masivo caudal de votos en las elecciones presidenciales de octubre de 1931 en las que resultó electo Luis M. Sánchez Cerro. Desde entonces, a pesar de ser 
ilegalizado y tenazmente perseguido por un largo periodo, el APRA mantuvo e incluso acrecentó su popularidad.

Cuando Flores Galindo escribía el ensayo mencionado, era escasa la investigación histórica que se había internado en las modalidades de constitución de los lazos entre el aprismo y los distintos sectores sociales que le dieron ferviente apoyo. La narrativa partidaria —en un rasgo que en líneas generales pervive hasta hoy- se concentraba en la trayectoria de la figura suprema de Haya de la Torre, y a lo sumo consignaba con orgullo el grado de adhesión popular que detentaba la causa por él encabezada. Reducido espacio tenían en cambio las formas de construcción y las prácticas que habían propiciado el nacimiento y la evolución del movimiento. Paulatinamente, no obstante, una serie de trabajos de diferente procedencia comenzó a llenar ese vacío, hasta hacer de la cuestión de los comienzos del APRA como fenómeno popular uno de los interrogantes clásicos de la historiografía sobre el Perú contemporáneo (una preocupación análoga a la que décadas antes había presidido las investigaciones sobre los orígenes del peronismo en Argentina). En 1975 se disponía ya del estudio pionero de Peter Klarén, en el que las raíces sociales de la sólida implantación del aprismo en el norte peruano se cifraban en el descontento que el avance de las grandes haciendas azucareras, ligadas al capital extranjero, había ocasionado en sectores medios y en trabajadores rurales. ${ }^{2}$ Con posterioridad, vieron la luz trabajos que remitían los orígenes del APRA a la experiencia de las Universidades Populares, que hacían foco en la dinámica de movilización abierta con la caída de Leguía y las elecciones presidenciales de 1931, o que vinculaban la conformación del aprismo como hecho multitudinario con atributos que lo emparentaban con estructuras de creencia de tipo religioso. ${ }^{3}$ Más recientemente, otro abanico de aproximaciones — por lo general circunscriptas a espacios regionales - se propuso reconstruir con mayor precisión la trama de actores, prácticas y discursos que en

2 Klarén 1970.

3 Klaiber 1975 y 1978; Cicarelli 1973; Stein 1980; Vega-Centeno 1991; y Burga y Flores Galindo 1994: 309-324. 
diversas situaciones intervino en la configuración inicial del APRA. Así, descentrando el foco de la imagen que privilegiaba el vínculo entre líder y masas, comenzaron a ser ponderados otros grupos y figuras que actuaron como mediadores y activos constructores del nuevo partido: élites y hacendados locales, maestros, obreros y artesanos involucrados en el desarrollo de Universidades Populares, «intelectuales menores», etc. Este conjunto de miradas puso de relieve los diferentes «usos del aprismo» que, dentro de un prisma general nacionalista y anti statu quo - que incluyó tempranamente posiciones anticomunistas-, tuvieron lugar en distintas zonas del Perú a comienzos de los años treinta. ${ }^{4}$

No obstante estos avances, que han renovado de manera considerable el mapa de los estudios sobre el aprismo, un terreno que curiosamente ha recibido atención solo tangencial es el de su cultura impresa. El movimiento liderado por Haya de la Torre cultivó profusamente, como estrategia de construcción y fortalecimiento de la identidad partidaria, la producción y circulación de ingentes cantidades de materiales impresos. La tarea, que abarcó desde un amplio repertorio de libros y folletos (publicados en su mayoría en los primeros años de la década de 1930) a un espectro incalculable de pequeños periódicos, boletines, afiches y volantes, tuvo su más célebre insignia en el diario La Tribuna. Fundado en mayo de 1931, este periódico se transformó rápidamente en un órgano muy difundido. Y aunque ocupa un lugar de privilegio en la memoria y en los mitos partidarios, aún permanece como un elemento poco explorado por los historiadores, que a lo sumo lo han utilizado como fuente de información. En cambio, no ha sido casi interrogado en sus funciones de artefacto que, en el despliegue de su materialidad y en los diversos usos de los que fue objeto, contribuyó decisivamente al apuntalamiento del APRA como fenómeno popular. ${ }^{5}$

En diálogo con algunas de las orientaciones que en la actualidad renuevan la historia de la prensa periódica en América Latina, este artículo

4 Nugent 1997; Taylor 2000; Glave y Urrutia 2000; Heilman 2006; Giesecke 2010; Drinot 2012; Bergel 2013a; y Aguirre 2014.

5 Una primera indagación panorámica de la cultura impresa del APRA durante el periodo 1930-1945 puede hallarse en Bergel 2013 b. 
se propone reconstruir la trayectoria inicial de La Tribuna desde sus prolegómenos al momento en que sufre su primera clausura por parte del gobierno de Sánchez Cerro, en febrero de 1932. Durante ese lapso, en su doble condición de objeto de circulación material y de espacio privilegiado de discurso, el periódico fue un agente de peso en la construcción inicial de un "pueblo aprista». Pero si nos proponemos recuperar el lugar de La Tribuna en la historia de conformación del APRA como movimiento de masas, al mismo tiempo tomamos distancia del que suele otorgársele en la mitología partidaria, que en ocasiones ha querido ver en este diario un órgano pionero dentro del ámbito de la prensa popular peruana. Como habremos de ver, si el de La Tribuna fue un experimento exitoso, fue menos por lo que tenía de original que por haber inscripto su apuesta política dentro de los cánones del periodismo escrito moderno que ya contaba con antecedentes - de los que sus mentores tomaron debida nota- en el Perú y en el resto del continente.

\section{PREHISTORIA DE UN DIARIO}

En la década de 1920, Haya de la Torre y el puñado de jóvenes provenientes de la experiencia de la Universidad Popular González Prada que habían sido enviados al destierro por el gobierno de Leguía fueron protagonistas de un exilio de tipo proselitista que rápidamente los llevó a destacarse en los medios estudiantiles e intelectuales de las distintas ciudades europeas y americanas que les tocó transitar. Impulsado por el eco positivo que hallaba en la opinión pública de esos destinos, nacía así el proyecto del APRA, que en efecto logró sobresalir dentro del haz de iniciativas de corte americanista y antiimperialista que florecía en el periodo. Una serie de rasgos de ese experimento contribuye a explicar el éxito con que el nombre y las orientaciones del emergente movimiento consiguieron instalarse a nivel continental: el afanoso uso de la correspondencia, que mantuvo en constante coordinación — aún en prescindencia por largos ańos de contactos cara a cara - y en situación de renovado compromiso político al conjunto de exiliados dispersos en distintas latitudes; el dinamismo del que hicieron permanentemente gala; la ostentación de credenciales simbólicas que los ubicaban como miembros 
salientes de la autoproclamada nueva generación universitaria americana; la hábil capacidad de interlocución, tramitada también a menudo por vía epistolar, con figuras y actores de distintos países que colaboraron en la amplificación de la prédica del movimiento; y la insistencia, sobre todo de Haya, en difundir la idea de que el naciente aprismo se granjeaba simpatías y adhesiones — sin perjuicio de la diferencia existente entre ambos tipos de vínculo- en numerosos rincones del continente. Todos esos factores se vieron atravesados, en mayor o menor medida, por un sesgo prominente de la praxis política desplegada entonces por el núcleo de jóvenes apristas: el del ejercicio incansable de la escritura. ${ }^{6}$

En efecto, el laborioso grupo de jóvenes activistas que dio origen al APRA se entrenó rápidamente en esa actividad crucial para las labores de propaganda. En las cartas en las que, en tono progresivamente paternalista y prescriptivo, Haya encomendaba tareas a la red de desterrados, la publicación de artículos de opinión, proclamas y cartas públicas en órganos gráficos guardaba un lugar de primer orden. Así podía manifestarlo a Eudocio Ravines - entonces uno de los principales puntales en los que se apoyaba el líder trujillano- en una misiva enviada desde Londres a París:

No importa repetir. Al contrario, hay que repetirse mucho, pero extender también mucho la labor de propaganda. Pero hay que escribir. Uno de ustedes debe escribir artículos incesantes sobre el problema indígena peruano, revelar abusos y conmover la opinión pública con una propaganda indigenista vívida que conmueva y justifique la revolución [...]. Otro debe ocuparse de asuntos estudiantiles, persecuciones, acción de la UP, en este orden, y recuerdo constante del heroísmo de la juventud peruana [...]. Otro o el mismo debe seguir diciendo que la UP fue la primera tribuna antiimperialista de América Latina, definida en un sentido económico, y que la UNIDAD de América es nuestro lema, etc. ${ }^{7}$

6 En anteriores ensayos me he ocupado de esos rasgos constitutivos de la cultura política del aprismo en su primera fase de existencia en los ańos veinte; véase Bergel 2009, 2010 y 2014. Otros trabajos recientes que han realizado también aportes en la misma dirección son Manrique 2009; García-Bryce 2014; Dorais 2014 y 2017; Landázuri 2015; y Wallace 2017.

7 Carta de Víctor Raúl Haya de la Torre a Eudocio Ravines, Londres, 26 de octubre de 1926 (Planas 1986: 204-205; el énfasis es mío). 
Por sus propias inclinaciones, jóvenes como Manuel Seoane, Luis Heysen, Magda Portal, Carlos Manuel Cox, Oscar Herrera o Eudocio Ravines se encargaron de satisfacer ese tipo de directivas de Haya. Pero fue sobre todo este quien lideró las labores de escritura y, aún más, de publicación incesante de artículos y ensayos breves. Según refirió en una ocasión, algunos de los textos que compuso durante su viaje a Rusia, en 1924, se editaron «en más de cincuenta periódicos o revistas de Sur y Centroamérica, las Antillas y México». ${ }^{8} \mathrm{Y}$ aun cuando esa cifra pueda estar inflada, lo cierto es que los escritos de Haya aparecieron en una amplísima gama de publicaciones de esos años.

En ese contexto de agitación propagandística, no causa asombro que entre los desterrados haya circulado la idea de pergeñar una publicación propia. En la correspondencia hay incluso alusiones tempranas, aunque vagas y circunstanciales, al proyecto de un diario. En carta a Oscar Herrera desde París, en enero de 1927, Ravines menciona al pasar la necesidad de juntar fondos "para el sostenimiento del periódico que saldrá pronto». Algunos meses después, es él mismo quien le desaconseja a Haya esa iniciativa: «más que del folleto dices que eres partidario del periódico. Pero es que no hay plata»?

Las referencias son borrosas, pero es indudable que esta primera idea de concebir un diario propio está vinculada al periodo de febril activismo que se desencadena luego de que a fines de 1926 apareciera el manifiesto "¿Qué es el APRA?», verdadera carta de presentación del movimiento (reproducido por doquier en numerosos países). De hecho, es entre 1927 y 1928 cuando ven la luz efímeras revistas de las células de desterrados apristas recién creadas en Buenos Aires, La Habana, Santiago de Chile y México. ${ }^{10}$ No obstante, la publicación de mayor envergadura que se entrevé en las alusiones epistolares no llegó a materializarse. De un lado,

8 Haya de la Torre 1932: 91.

9 Carta de Eudocio Ravines a Oscar Herrera, París, 6 de enero de 1927; y carta de Eudocio Ravines a Víctor Raúl Haya de la Torre, París, 1 de mayo de 1927 (ambas provenientes del Archivo Armando Villanueva del Campo).

${ }^{10}$ Sobre Indoamérica, la revista de la célula de desterrados apristas en México que salió durante unos meses en 1928, véase Melgar Bao 2018. 
como se desprende de la carta de Ravines a Haya, las penurias económicas que a menudo acompañaron el exilio de los jóvenes peruanos hacían difícil imaginar la concepción de un medio gráfico sustentable. De otro, el propio carácter nómada de los desterrados, que vivieron el exilio en peregrinaje constante entre varias ciudades y continentes, conspiraba contra esa posibilidad, que requería indudablemente un arraigo duradero en un territorio definido. Pero además, como ya fue señalado, los apristas hallaron muchas facilidades para publicar sus textos de propaganda, junto con otros periodísticos y de opinión dedicados a otras materias (políticas, sociológicas, literarias y aun deportivas), en una extensa serie de publicaciones. Esa estrategia de colaboración externa, múltiple y deslocalizada en innumerables diarios y revistas con seguridad aparecía como más apropiada en relación con los objetivos de dar a conocer el nombre y las ideas del APRA en ámbitos geográficos distantes y variados. Y a todo ello se sumaba una razón adicional de peso: el tipo de vínculo entablado por Haya de la Torre y algunos otros jóvenes exiliados con ciertos caracterizados medios gráficos continentales contemplaba el pago por los textos enviados. En una nota introductoria al libro que compilaba sus artículos elaborados desde Inglaterra en 1926 y 1927, el jefe trujillano culminaba agradeciendo a La Voz del Interior y Critica: «a ambos diarios argentinos debo recuerdo grato, porque respetaron mi libertad de opinar y retribuyeron mi trabajo intelectual. Ambos me ayudaron a salvar las dificultades premiosas de mi nada holgada economía». ${ }^{11}$ De modo que ese conjunto de factores confluyó para que esas primeras menciones de 1927 a la posibilidad de montar un diario se evaporaran en la correspondencia de los años siguientes.

La idea reaparece, y con mayor ímpetu, luego de la caída de Leguía en 1930. El contexto había entonces variado significativamente en varios planos. De un lado, ante el cambio de gobierno los jóvenes desterrados deciden volver coordinadamente al Perú. Es allí cuando los primeros retornados, junto con algunos otros simpatizantes de Haya que no se habían exiliado, fundan en septiembre de ese año la Sección Peruana

${ }^{11}$ Haya de la Torre 1932: 12. 
del APRA, luego transformada en Partido Aprista Peruano (PAP). Si hasta entonces el aprismo en el Perú era una referencia conocida por grupos reducidos, desde ese momento empezó a constituirse, y a una velocidad progresiva, como un nuevo partido que echaría raíces cada vez más extensas en todo el país. En ese marco, en la etapa que entonces se abría volvería a ingresar en las discusiones el proyecto de un medio gráfico propio. Pero, de otro lado, esa situación partidaria se solapaba con un escenario de efervescencia dentro del periodismo peruano. En palabras de Juan Gargurevich, tras la caída de Leguía se experimentó una "verdadera explosión periodística», que se verificó en la fundación de una miríada de diarios nuevos y en el relanzamiento o la renovación de otros ya existentes. ${ }^{12}$ Ese hecho se hallaba traccionado ciertamente por la política, puesto que muchos de esos periódicos nacieron como plataforma de algún grupo o movimiento, o, un poco después, como base de apoyo para algunos de los candidatos que concurrirían a las elecciones presidenciales de 1931. Pero, al mismo tiempo, era impulsado por una generación de periodistas que encabezó iniciativas innovadoras en materia de lenguajes y formatos gráficos. Ya en las primeras décadas del siglo figuras como Antonio Miró Quesada, al comando de El Comercio, o Clemente Palma, director de La Crónica, introdujeron cambios estilísticos y nuevas secciones que buscaban satisfacer los requerimientos de un público crecientemente diversificado y en expansión. A esos esfuerzos se sumaría, hacia 1930, el aporte de personalidades más jóvenes que, como Federico More o Enrique Balerezo Pinillos (Gastón Rogger), compartían una similar vocación de modernización periodística. ${ }^{13}$ En suma, la expansión de la prensa que tenía lugar en el periodo

\footnotetext{
${ }^{12}$ Gargurevich 1991: 148 y ss.

${ }^{13}$ Por caso, en un editorial de su periódico La Noche titulado «La función de la prensa», Rogger consignaba que mientras en el pasado «la prensa en el Perú ha respondido por lo común a una exclusiva finalidad política», el órgano que lideraba «no amolda su relación con el público a las opiniones o los intereses de ningún grupo beligerante dentro del momento actual o dentro de las futuras proyecciones de la política en el Perú» (La Noche. Núm. 9, 6 de noviembre de 1930, p. 1). Ciertamente, en ese editorial se sugería un esquema simplificador de la evolución de los diarios, que en rigor llevaban décadas ya de paulatina relajación de sus compromisos político-partidarios y de tramitación de lógicas
} 
se vio incentivada tanto por la coyuntura política que se originó con el fin del leguiísmo, como por las tentativas modernizadoras encabezadas por nombres que a la postre ocuparon un lugar de peso en la historia del periodismo gráfico del país. ${ }^{14}$

En ese contexto, ya en los primeros cónclaves organizativos del flamante PAP aflora la idea de editar una publicación con el fin de apuntalar el desarrollo del partido. Sobre el final del acta de la reunión fundacional del 20 de septiembre de 1930, se establecía lo siguiente: «se dará a publicidad un semanario intitulado "APRA" para la defensa y propagación de sus postulados». Desde entonces, según se desprende de las reseñas de las subsiguientes asambleas organizativas que pasaron a la posteridad en el llamado "Cuaderno Rojo» (disponible a la consulta solo desde 2015, gracias a la lujosa edición facsimilar que Javier Landázuri llevó a cabo siguiendo un designio de Armando Villanueva del Campo), el tema ocupa un lugar preferencial. En la cuarta reunión, el 9 de octubre, la Secretaría de Propaganda a cargo de Alcides Spelucín informa de la próxima salida del órgano, "cuya tirada alcanzará la cantidad de 5000 ejemplares». Asimismo, se deja constancia de que según el plan editorial «su primer número está dedicado a estudiar los problemas americanos», mientras que «el segundo número enfocará los problemas nacionales». ${ }^{15}$

En efecto, el 12 de octubre de 1930 aparecía la revista $A P R A$, órgano oficial partidario. Como se adivina ya de la lectura de los apuntes que recogieron las discusiones asamblearias, se trataba de una publicación de corte político-intelectual, afín todavía al movimiento de vanguardia que hasta entonces había sido el aprismo. Amén de algunos pocos recuadros informativos, la revista estuvo en lo fundamental compuesta, número a número, por el tipo de ensayo doctrinario breve que había sido habitual entre los desterrados. Fue por ello que a poco andar, y cuando el APRA

estrictamente periodísticas. Pero lo que interesa es resaltar cómo ese texto testimonia el peso que en la prensa adquirían las orientaciones que daban preeminencia a uno de los principales vectores de la modernización: el de la función de informar.

${ }^{14}$ Mendoza Michilot 2013. Sobre la figura de More, véase Gonzales 2006.

15 "Acta de inauguración de la Sección del APRA» y «Acta de sesión del Comité Directivo del APRA», Lima, 20 de septiembre y 9 de octubre de 1930 (Landázuri 2015, I). 
daba ya primeras muestras de la notable capacidad expansiva que acompañaría su andar en los meses y años siguientes, la idea del periódico volvió a salir a flote. En principio, se discute la participación de integrantes de la directiva partidaria en diarios que personas de recursos planeaban editar. ${ }^{16}$ Esas gestiones no prosperan, pero el proyecto del órgano de prensa gana espacio en las discusiones, incluso de las epistolares con las figuras que aún no habían regresado al Perú. Por caso, en carta del 31 de enero de 1931, Haya — quien volvería al país recién en julio de ese año- escribía a Luis Alberto Sánchez, recién integrado a las filas partidarias, que «algo que me parece magnífico es el plan del diario. Hay que luchar por él decididamente. Lo necesitamos. Porque solo con un fuerte movimiento de opinión tendremos respaldo». ${ }^{17} \mathrm{La}$ idea avanzaba, y en el acta de la sesión del Comité Ejecutivo del 24 de marzo se señalaba que la «Sec. Gral. Informa sobre la próxima salida del periódico, órgano del Partido; así como de la constitución del cuerpo de Redacción» (cuyos miembros no se informan). ${ }^{18}$

La necesidad del órgano propio estaba ya en la primera fila de las aspiraciones partidarias, y parecía ser un objetivo compartido por todos. Durante un tiempo, se pensó que la publicación oficial podría virar hasta asumir la fisonomía del medio anhelado. Incluso así se dio a conocer en las páginas del propio semanario: "APRA se transforma en diario, para servir mejor las aspiraciones del país, que son las del Partido Aprista Peruano [...] hoy no bastan las columnas de nuestra revista para sostener sus ideales con el vigor que la acción reclama». ${ }^{19}$ Finalmente, $A P R A$ continuaría saliendo en su mismo formato, pero se le añadiría otra iniciativa: un periódico enteramente nuevo que se acordó llamar La Tribuna.

16 «Sesión del Comité Directivo de 27 de diciembre de 1930» y «Sesión del Comité Ejecutivo Nacional del 14 de enero de 1931» (Landázuri 2015, I).

${ }^{17}$ Haya de la Torre, Víctor Raúl a Luis Alberto Sánchez, Berlín, 31 de enero de 1931 (Haya de la Torre y Sánchez 1982, I: 33).

18 «Acta de la sesión del C.E.N., realizada el 24 de marzo de 1931» (Landázuri 2015, I).

19 "Nuestro diario: a los Sordos y a los Zurdos». APRA. Segunda Época. Núm. 5, 26 de marzo de 1931, p. 2. 


\section{SEOANE Y SÁNCHEZ ENTRAN EN ESCENA}

En esa misma nota de anuncio se informaba que «dirigirá el diario $A P R A$ el líder aprista Manuel Seoane», que entonces viajaba por tierra desde Buenos Aires, donde había pasado sus años de exilio. No sabemos las circunstancias en que se tomó tal decisión, pero sí que ella recaía en una figura que regresaba al Perú del destierro rodeada de pergaminos. En la capital argentina, en efecto, Seoane se había destacado en distintos espacios, y su nombre se había proyectado incluso hacia otros países de la región, algunos de los cuales había visitado ya como destacado dirigente aprista. ${ }^{20}$

Esa fama acumulada en el destierro sería reconocida por la opinión pública peruana. Y también en las filas del APRA, que comenzaban a observar en Seoane la silueta de mayor relieve detrás de Haya de la Torre en el escalafón partidario (precisamente, su rol de fundador y director inicial de La Tribuna tácitamente lo confirmaría en ese sitial). Ya en noviembre de 1930, en su primer regreso al Perú —fallido, puesto que debió volver a exiliarse en Buenos Aires pocas semanas después-, su retrato ocuparía la portada de uno de los primeros números de la revista $A P R A$. En una edición posterior, mientras se reseñaba elogiosamente la gira de conferencias con las que Seoane había ingresado al país por la sierra sur, se subrayaban también los méritos que lo habían llevado a sobresalir en el país del Plata. Entre ellos, se mencionaba el agasajo que en la hora de su partida le había tributado «un numeroso grupo de sus compañeros de periodismo». ${ }^{21} \mathrm{Y}$ es que su actuación en la prensa, sobre todo en el popular diario Crítica, comportaba uno de los aspectos que más se recordarían de su etapa argentina. Y el que, según varios testimonios, le permitió ser ubicado al frente del proyecto del diario partidario. Así ocurriría, por ejemplo, en la recapitulación ofrecida por Luis Alberto Sánchez, quien a la sazón lo secundó en la dirección del periódico:

Como Seoane tenía alguna experiencia obtenida en Crítica de Buenos Aires, y yo había sido presidente de la Asociación Nacional de Periodistas

\footnotetext{
${ }^{20}$ Sobre el exilio de Seoane en Argentina, véanse Bergel 2007 y Sessa 2010.

21 «La vuelta de Manuel Seoane». APRA. Núm. 7. Lima, 23 de noviembre de 1930, p. 4.
} 
del Perú, nuestros compañeros nos propusieron a la cabeza del «team». Por acuerdo unánime se fletó la fórmula Seoane-Sánchez para la dirección y subdirección del periódico al que titulamos La Tribuna. ${ }^{22}$

El comando del futuro diario quedaba entonces reservado para ese dúo. Seoane y Sánchez, nacidos el mismo año, se conocían desde la adolescencia y habían trabado una estrecha amistad juvenil. La correspondencia entre ambos había sido muy fluida durante el destierro del primero en Buenos Aires, y había estado jalonada por un conjunto de temas entre los cuales los relativos a la escritura de textos y el mundo del periodismo ocupaban un lugar importante. Seoane además supo ser una influencia de peso en el proceso de politización de Sánchez y en su incorporación al APRA a comienzos de 1931. Con posterioridad, mantendrían conexión permanente por el resto de sus vidas, aunque la relación se vería atravesada por una dinámica de profundos celos y resentimientos. Las extensas memorias de Sánchez, en las que la figura de Seoane tiene una presencia casi mayor a la del propio Haya, reflejan cristalinamente las ambivalencias que surcaron el vínculo, tramado a un tiempo por el cariño y el recelo. ${ }^{23}$

Esa mecánica de resquemores, sin embargo, no se había despertado aún a comienzos de los años treinta. Aunque la cita retrospectiva de Sánchez revela algo de la competencia entre ambos que sobrevendría luego, por entonces era un admirador sin ambages de la actuación pública de su amigo de juventud. Es muy probable incluso que la cuestión del periódico partidario haya formado parte de sus intercambios epistolares, aunque en las cartas cruzadas que se han conservado no hay rastros directos de ello. En cambio, en otra remembranza Sánchez escribirá que, en las semanas que pasó en Lima en su regreso de noviembre de 1930, Seoane «me atormentó con la idea de "sacar" un periódico». ${ }^{24}$ Sea como fuere, una vez que el diario vio la luz ambos hombres parecen en efecto haber

${ }^{22}$ Sánchez 1987b: 12.

23 Bergel 2017.

${ }^{24}$ En esta evocación de Sánchez, la proyección retroactiva de un clima de competencia es más evidente. "Su reciente experiencia como cronista de Crítica de Buenos Aires», escribía en referencia a Seoane, «apabullaba hasta mis largos años de práctica en Mundial de Lima» (Sánchez 1961). 
hilvanado una dupla que funcionaba en armonía y que se potenciaba mutuamente. En otro pasaje de sus memorias Sánchez deja esa impresión:

Yo había sido cofundador del diario de mi partido. Durante sus primeros meses lo escribíamos en un 80 por ciento Manuel Seoane y yo. Llegamos a compenetrarnos de tal modo que, a menudo, un editorial comenzado por él, lo terminaba yo, sin que se notara el cambio de mano. ${ }^{25}$

La Tribuna todavía demoraría casi dos meses en ver la luz en relación con lo anunciado en la revista $A P R A$. Lo haría el 16 de mayo de 1931, luego de que lograra reunirse un fondo económico inicial a partir de donaciones particulares. Entre los elementos de tono heroico que en la narrativa partidaria rodean las referencias al diario, suele señalarse la abnegada actividad militante del improvisado plantel de periodistas, que durante los primeros meses apenas si recibió paga por la labor desarrollada. El nombre de Seoane también reluce en este aspecto, puesto que todos los testimonios coinciden en concederle un rol fundamental en la preparación de quienes lo acompañarían. Según la reconstrucción de Manuel Solano, uno de sus más fieles laderos, en una asamblea realizada en el local partidario apenas regresado al Perú, en abril de 1931, Seoane sorpresivamente lanzó a los presentes la pregunta de si se animaban a trabajar como periodistas en el proyectado diario. En sus recuerdos, el flamante director «nos dio algunas indicaciones y habló con mucha franqueza. Tanta que las filas se ralearon y fuimos quedando algo más de una docena [...] Seoane nos dio unas cuantas breves explicaciones sobre la técnica de la información y el titulaje. Sobre esto insistió con verdadera manía». ${ }^{26}$

Llegados a este punto, corresponde señalar que, entre los múltiples símbolos que pueblan la memoria aprista — que hasta el día de hoy ha

${ }^{25}$ Sánchez 1987c: 216. Aunque la gran mayoría de los artículos de La Tribuna se publicaba sin firma, es muy probable que la gravitación que la cita otorga a la dupla en la factura del periódico sea exagerada. Junto con Sánchez y Seoane el diario reunía una serie de reconocidas figuras, algunas de las cuales hizo también carrera en el periodismo gráfico. En esa lista se puede mencionar a Manuel Solano, Bernardo García Oquendo, Alcides Spelucín, Arturo Sabroso, Luis López Aliaga y Hugo Otero, entre otros.

${ }^{26}$ Solano 1961. 
funcionado hasta la exasperación como un carburante emocional indispensable para la vida del partido-,${ }^{27}$ La Tribuna encarna uno de los mitos infaltables a la hora de evocar las glorias del pasado. Esa situación a menudo ha conducido a observar en la historia del periódico rasgos pretendidamente únicos, singulares o aun fundacionales. Por ejemplo, en los deslizamientos que se operan en los relatos partidarios que, a la hora de calibrar el peso del diario en la historia del APRA, terminan otorgándole un lugar de excepción en la trayectoria del periodismo peruano in toto. ${ }^{28}$ Lo cierto es que si la emergencia de La Tribuna es colocada en el contexto más amplio del campo de periódicos en el que se insertaba, esa pretendida excepcionalidad debe ser relativizada. Y es que el diario aprista no pudo sino inspirarse en otros modelos y lógicas ya establecidas en el concierto de la prensa peruana y latinoamericana. Hemos señalado ya los lazos que unieron a Seoane con Crítica. Diversos indicadores sugieren que ese vínculo no fue superficial. Andrés Townsend Ezcurra ha escrito que, merced a esa relación, cuando luego de 1932 la represión ejercida por el gobierno de Sánchez Cerro trajo aparejada una nueva y más amplia ola de destierros, las salas de redacción de Crítica "servían de sede informal a los exiliados apristas de la capital argentina». ${ }^{29}$ La cercanía de Seoane con el diario del afamado Natalio Botana se verifica asimismo en la naturalidad con la que Ciro Alegría le pide que le consiga allí trabajo a mediados de los años treinta. ${ }^{30}$ Todo lo cual parece apuntar a que en efecto Crítica, que precisamente en la década de 1920 adquiere ribetes de verdadera sensación periodística a partir de haber revolucionado los estilos y formatos de la prensa y de haber conquistado una enorme popularidad (hacia fines del decenio acusaba un tiraje de 300 mil ejemplares), debe haber sido para Seoane una referencia ineludible

\footnotetext{
${ }^{27}$ Dos trabajos recientes que abordan desde diversos ángulos el lugar de la memoria y los mitos partidarios en el APRA son García-Bryce 2010 y Sessa 2014.

${ }^{28}$ Véase, por ejemplo, el artículo de Sabroso (1961), dirigente y periodista del diario.

${ }^{29}$ Townsend Ezcurra 1989: 276.

${ }^{30}$ Carta de Ciro Alegría a Manuel Seoane, Santiago de Chile, 7 de febrero de 1935 (Alegría 1978: 151-152).
} 
a la hora de proyectar un diario propio. ${ }^{31}$ Una circunstancia de la que nuevamente Solano, en otra rememoración, parece dar fe:

Como director de La Tribuna, Seoane, fue siempre un amigo, un camarada, pero muy exigente en el trabajo. El había laborado en varios diarios argentinos durante su destierro en ese país, y quiso darle la misma tónica a nuestro periódico. Cuando hablaba de periodismo en sus momentos de trabajo, lo hacía en lenguaje argentino, es decir, se valía de la jerga periodística de ese país, la cual se le había quedado profundamente grabado [sic]. ${ }^{32}$

En definitiva, la exitosa implantación popular de La Tribuna probablemente haya debido menos a sus elementos originales que al hecho de haber replicado facetas vinculadas a los cambios contemporáneos de las más renovadoras experiencias del periodismo gráfico disponibles en el continente. Sobre este punto señalemos de paso que la historiografía sobre los exilios latinoamericanos, que ha ampliado su campo de miras y se ha enriquecido notablemente en el último tiempo, en general no se ha detenido en el hecho de que uno de los posibles saldos benéficos de las experiencias de destierro del pasado en la región haya tenido que ver con la circulación transnacional de saberes y modelos periodísticos. ${ }^{33}$

Con todo, junto con el señalamiento del peso que en el diseño del diario aprista pudo tener la prensa argentina, hay que anotar influencias un tanto más generales y difusas, y que por eso han sido menos señaladas. Como indicamos con anterioridad, el campo periodístico peruano

${ }^{31}$ Sobre Crítica, el estudio de referencia (ya clásico, y que en Argentina dio impulso a una nueva historia cultural de la prensa periódica) es Saítta 1998.

32 Solano 1984: 377. Desde un ángulo más general, los lectores de La Tribuna pudieron anoticiarse también del impacto que la experiencia del exilio en el Río de la Plata había tenido para Seoane. En un texto a propósito de la conmemoración del 25 de mayo fecha patria argentina—- el director del diario escribía: «Yo no padezco un argentinismo oficial y de libro. Mi argentinismo es popular y en mangas de camisa [...]. Yo conocí a la Argentina cuando me interné en el alma de ese pueblo, viviendo sus ilusiones y sus dolores, mezclándome a la anónima masa de sus clases productoras» (Seoane 1931a). Posteriormente Seoane dedicaría incluso un libro completo a sus impresiones sobre el país austral titulado Rumbo argentino. Sondeos en el alma argentina (analizado en Sessa 2010).

${ }^{33}$ Un panorama de los estudios recientes sobre la problemática del exilio latinoamericano puede hallarse en Roniger y Sznajder 2013. 
no se hallaba yermo en el momento de aparición de La Tribuna. Por el contrario, tanto sus periódicos más antiguos - ejemplarmente, El Comercio - como los que se crearon en torno a 1930 estaban embarcados en procesos de modernización, de creación o renovación de secciones, y de atención de intereses de nuevos segmentos de público. Seoane y Sánchez se habían educado en la lectura de esa prensa, y habían colaborado de diversos modos en varias de sus expresiones. Por caso, en su vuelta a Lima de noviembre de 1930 el futuro director del órgano aprista comenzó a publicar en La Noche, que acababa de reaparecer. En suma, al ver la luz en mayo de 1931, La Tribuna se integraba a un campo periodístico en ebullición, que en cierto sentido había preparado ya el terreno para su emergencia como medio gráfico popular.

\section{LA TRIBUNA Y LA CONSTRUCCIÓN DEL PUEBLO APRISTA}

La aparición de La Tribuna coincidió con el periodo de aceleración del tiempo político previo a las elecciones presidenciales de octubre de 1931, un lapso en el cual el APRA adquiriría por primera vez una fisonomía de masas. A pesar del prolongado exilio de Haya y de otras jóvenes figuras provenientes del reformismo universitario que lo secundaban desde distintas ciudades americanas y europeas, las noticias relativas a la gestación y posterior evolución del aprismo no fueron del todo desconocidas en el Perú de la década del veinte. Tanto por la pervivencia de una memoria vinculada a la experiencia de la Universidad Popular González Prada, como por la difusión del nombre y las orientaciones del flamante movimiento a través de una tenaz política epistolar (que incluía la introducción subterránea de material de propaganda, una práctica que se intensificaría en los años treinta), algunos núcleos acotados permanecían a la expectativa del posible retorno de los desterrados. ${ }^{34}$ En provincias esos grupos, a menudo liderados por algún intelectual o dirigente local, se constituyeron embrionariamente como espacios apristas

${ }^{34}$ Stein 1980: 146-154; Klaiber 1975; y Bergel 2014. 
o protoapristas incluso antes de la caída de Leguía. ${ }^{35}$ Solo así puede entenderse que - de acuerdo con algunos testimonios - apenas medio año después de haberse fundado el PAP tuviera algún tipo de presencia efectiva en el conjunto de regiones del país. ${ }^{36}$ Pero sobre esos primeros círculos iniciales tuvo lugar, a gran velocidad y a lo largo de ese crucial año 1931, la construcción del aprismo como identidad asumida por decenas de miles de peruanos. Según observaba The West Coast Leader (órgano gráfico limeño que se editaba en inglés), antes de la creación del PAP «ni uno en un ciento había oído del APRA; hasta que ella se dejó sentir como el estallido de una bomba, ante el Perú atónito, como un partido bien organizado». ${ }^{37}$

Pues bien: a La Tribuna le cupo un rol de peso en esa fulgurante aparición del APRA y en su instalación en el centro de la vida política nacional como movimiento popular. ${ }^{38} \mathrm{El}$ tiraje de 25 mil ejemplares del que podía jactarse a meses de haber salido a la palestra es un indicador de su exitosa implantación. ${ }^{39}$ Pero más allá de ese dato, en su despliegue el periódico asumió un haz de funciones que colaboró en la penetración del partido en distintos segmentos sociales. Para empezar, y de un modo

35 Tal lo acontecido por ejemplo en Cajamarca y Chachapoyas, según la precisa reconstrucción de Taylor (2000) y Nugent (1997).

${ }^{36}$ Según un reporte del embajador norteamericano Fred Dearing al Departamento de Estado fechado en Lima el 22 de abril de 1931, los apristas «están conquistando sostenidamente adherentes, y se han atrincherado en todas las secciones del país» (Archivo NARA, Carpeta 5694, Washington DC; traducción mía del inglés).

37 Traducido y reproducido en La Tribuna [en adelante LT]. Núm. 127, 17 de septiembre de 1931, p. 2.

${ }^{38}$ Aunque en una escala más reducida, otros periódicos regionales parecen haber jugado un papel en la misma dirección. Sin detenerse en un análisis pormenorizado, Klarén (1970: 226) y Taylor (2000: 46) han observado el rol que en la expansión del aprismo tuvieron los diarios El Norte, de Trujillo (reaparecido luego de la caída de Leguía), y El Perú, de Cajamarca.

${ }^{39}$ El hecho, certificado por un escribano, es anunciado en las páginas del periódico. «Ayer pasamos los 25 mil ejemplares». LT. Núm. 198, 17 de noviembre de 1931, p. 7. En carta privada en 1932 a un amigo espańol, Seoane daba una medida ilustrativa (aun cuando exagerada) del fenómeno: un año antes, le contaba, «mi periódico La Tribuna sobrepasaba todos los récords de tirada conocidos en Lima» (la carta se reproduce en el diario El Sol, Madrid, 5 de mayo de 1932). 
cada vez más marcado — que hacía diferencia con el tipo de dispositivo que había sido y que continuaría siendo la revista $A P R A-$, La Tribuna ejerció un rol facilitador del proceso de emergencia y desarrollo de la densa red de células e instancias regionales, sectoriales y hasta barriales que surgió velozmente bajo el paraguas del aprismo. En secciones como «Actividades apristas», pero también en un amplio abanico de pequeñas notas informativas, el diario daba cuenta de — a la vez que impulsabala formación de una miríada de espacios organizativos. Por citar solo un ejemplo, en una misma página del diario dos recuadros daban a conocer que se habían conformado el Comité Departamental de Huancavelica y la Célula Aprista de la Escuela de Ingeniería de Lima. ${ }^{40}$ A tono con el descentralismo defendido por los máximos dirigentes partidarios, la mayoría de esos breves informes aludían a la constitución de comités en zonas distantes de la capital, a veces incluso en distritos poco poblados. ${ }^{41}$ Además de ello, el diario ofreció espacio para que los grupos que florecían en esos espacios regionales pudieran hacer oír su propia voz. El 5 de junio se publicaba un texto de un dirigente de Pallasca, provincia de Ancash; un día después, quien se expresaba era el grupo que hacía la revista Tierra, del Comité de Celendín; pocos días más tarde, era desde Canta que se daba respuesta al "generoso ofrecimiento de La Tribuna», a través de una nota de un dirigente que afirmaba que los naturales de esa provincia «no podemos permanecer indiferentes ante la intangible realidad que nos muestra el Aprismo». ${ }^{42}$ Esa serie de breves notas

40 "Comité Departamental de Huancavelica» y «Células apristas de estudiantes de Ingeniería». LT. Núm. 10, 24 de mayo de 1931, p. 8.

${ }^{41}$ Por ejemplo: «Se instaló el comité aprista de Morococha» (LT. Núm. 41, 24 de junio de 1931, p. 11); o «Parinacochas. Organización de la célula aprista» (LT. Núm. 71, 23 de julio de 1931, p. 8).

${ }^{42}$ Arias Bulnes, Oswaldo, «Los apristas pallasquinos no hacemos política de círculo; queremos sentar un precedente único de moralidad y honradez». LT. Núm. 22, 5 de junio de 1931, p. 8; «Con el APRISMO haremos patria grande y progresista». LT. Núm. 23, 6 de junio de 1931 p. 5; y Yalán Hurtado, Roberto, «Canta. Luchemos contra el gamonalismo y el tinterillaje». LT. Núm. 30, 13 de junio de 1931, p. 8. En su importante trabajo sobre la emergencia de las masas a la vida política en la coyuntura que se abre con la caída de Leguía, Steve Stein ofrece una imagen que sobreestima la capacidad del PAP de incorporar disciplinadamente cada uno de los grupos de acólitos que se colocaban 
informativas y pronunciamientos de figuras locales y grupos regionales, que son una constante en las páginas del diario en esos frenéticos meses de 1931, tenía por cometido tanto mostrar la presencia cada vez más extendida del APRA en el conjunto del territorio del país (un elemento que aspiraba a contagiar de entusiasmo y voluntad organizativa a los lectores y grupos de otras jurisdicciones) como devolver a cada comarca que se hacía partícipe de la aventura del novel movimiento una imagen según la cual, a partir de haber adquirido visibilidad como pequeńa parte de un todo bullente, era preciso redoblar esfuerzos para colocarse a la altura de los desafíos encerrados en la apuesta del APRA. Un discurso informativo pero con aristas prescriptivas y normativas será habitual en la prédica de La Tribuna - y de los actores a los que el diario prestaba voz-, siempre al servicio tanto de ensalzar la obra ya realizada como de apelar a la multiplicación de los niveles de movilización y compromiso.

El diario podía intervenir aún más directamente en la configuración de espacios de militancia, fungiendo como canal de convocatoria concreta a eventos y reuniones. En sus páginas podían leerse cotidianamente llamados como el que sigue: "Se cita a los compañeros miembros de la Junta Directiva [del Comité distrital de Miraflores] a la reunión que con carácter de extraordinaria se llevará a cabo el día 5»; o también: «Se cita a los compañeros y simpatizantes vecinos de Surquillo a la sesión de la Junta general que tendrá lugar el día martes 30 de junio». ${ }^{43}$ Con arreglo a una búsqueda por encuadrar la vertiginosa expansión del movimiento dentro de un marco de orden y disciplina (un objetivo sobre el que el propio Haya no cesaría de insistir), fue también habitual que $L a$ Tribuna diera a conocer las listas de cargos de cada comité regional. En la misma vena, el diario fue además medio privilegiado en la organización de los Congresos Departamentales que comenzaron a realizarse hacia mayo y que culminaron en el primer Congreso Nacional partidario en

bajo órbita del partido (Stein 1980: 60-161 y 203-212). Aunque no es materia de este artículo, señalemos que las investigaciones más recientes sobre espacios regionales que mencionamos antes muestran el grado de relativa autonomía con que se conformaban; véase, por ejemplo, Heilman 2006.

${ }^{43} L T$. Núm. 22, 5 de junio de 1931, p. 2; y LT. Núm. 47, 30 de junio de 1931, p. 8. 
agosto. Todo ello redundaba en una imagen que cualquier lector del periódico no demoraba en obtener: la de un partido que se construía desde distintas regiones y localidades que eslabonaban un movimiento de efectiva presencia nacional.

Ese rol vertebrador de la vida partidaria hizo de La Tribuna un artefacto constituyente de la presencia callejera de los militantes apristas. En la medida en que sus páginas tanto narraban (si ya habían ocurrido) como propiciaban (si se trataba de hechos aún por venir) una multitud de encuentros y «actuaciones», espacio público y periódico establecieron una relación virtuosa de retroalimentación. Ese continuum entre una y otra instancia se hizo más patente en tanto rápidamente el diario adquirió estatus de símbolo partidario, y como tal se vio involucrado en los enfrentamientos que jalonaron los meses previos a las elecciones. En uno de sus libros de memorias, el histórico dirigente aprista Armando Villanueva del Campo se recordaría en ese agitado 1931 polemizando acaloradamente con adolescentes que como él rondaban los quince años: "caminábamos discutiendo de política, unos con El Comercio en la mano y otros con La Tribuna». ${ }^{44}$ Las propias instalaciones del periódico fueron a veces sede física de manifestaciones, algunas de ellas espontáneas. A comienzos de junio, cientos de pequeños ahorristas que protestaban por la confiscación de sus depósitos tras la quiebra del Banco del Perú y Londres redirigen su marcha: «De entre los manifestantes salió una voz: ${ }_{¡} V a m o s$ a La Tribuna!», relataba el propio diario, que describía a continuación cómo el propio Seoane recibió al nutrido grupo e improvisó desde un balcón un discurso que aludía a la justicia del reclamo que lo congregaba. El hecho, que mereció la portada de la edición del día siguiente, se ilustraba con una foto de la muchedumbre agolpada frente a la redacción. ${ }^{45} \mathrm{En}$ otras ocasiones, el diario aspiraba a ser un factor no solo de movilización de los lectores, sino de adiestramiento en maneras específicas de ocupación de la calle. En agosto, cuando Haya de la Torre llegó finalmente a

\footnotetext{
${ }^{44}$ Macera y Villanueva del Campo 2011: 51.

45 «Reclaman la devolución de sus ahorros. Los depositantes de la Sección Ahorros del Banco P. y Londres realizaron un mitin. Una manifestación de simpatía a "La Tribuna"”. LT. Núm. 19, 2 de junio de 1931, p. 1.
} 
Lima luego de ocho años de ausencia, La Tribuna instó a su público a sumarse al estelar acto de Plaza de Acho, donde el líder aprista daría un histórico discurso, y además prescribió minuciosamente los modos en que debía acudirse a la cita en un largo artículo titulado «Instrucciones a los manifestantes» a cargo de la Secretaría de Disciplina del partido. ${ }^{46}$ Esa función de vaivén entre la letra del periódico y la práctica del comité o la calle se aprecia asimismo en la reiterada cobertura que tienen en el diario las «giras» de dirigentes de la plana mayor del partido. «Sigue la gira triunfal de los compañeros Pedro Muñiz y López Aliaga. Llegaron a Jauja», se anunciaba en una edición; "La gira de los cc. Oscar Herrera y Arturo Sabroso por la provincia de Chancay», se informaba en otra. ${ }^{47}$ La serie viaje-acto-discurso público de un amplio espectro de figuras conformaría un mecanismo fundamental para la penetración territorial del partido, y las páginas del periódico nuevamente oficiarían tanto de espacio que daba a conocer las próximas presentaciones públicas como repositorio que proyectaba el eco de las ya acontecidas. ${ }^{48}$ El más resonante de esos tours proselitistas fue el emprendido por Haya de la Torre desde el instante mismo en que ingresó al Perú, a través del puerto norteño de Talara. La gira del jefe partidario involucró numerosas ciudades y avanzó causando sensación a su paso (como, en menor escala, ocurría con los viajes de otros líderes). Por caso, el multitudinario acto que encabezó en Cajamarca, debidamente registrado en las páginas de La Tribuna, representó un hito para la afirmación del partido en ese departamento. ${ }^{49}$

La implantación del periódico aprista en la trama urbana limeña se vio favorecida por una deliberada política de seducción de los niños repartidores de diarios (los «canillitas»). A sabiendas de su rol clave como

\footnotetext{
46 «Instrucciones a los manifestantes». LT. Núm. 63, 15 de agosto de 1931, p. 7.

${ }^{4} L T$. Núm. 115, 5 de septiembre de 1931, p. 6; y LT. Núm. 127, 17 de septiembre de 1931 , p. 8.

${ }^{48}$ Con relación al impacto de esta práctica en la inserción territorial del APRA, en una de las primeras ediciones del diario el escritor puneño Emilio Vásquez informaba que «en Puno las ideas apristas han hecho rápidamente numerosos prosélitos. La gira de nuestro compañero Heysen ha de traducirse, estoy seguro, en un mayor fervor por nuestro ideario entre las masas apristas» (Vásquez 1931).

49 Taylor 2000: 49-50.
} 
engranaje en la distribución, La Tribuna buscó incluirlos como brazo partícipe de su apuesta político-periodística, elogiando su entusiasmo y compromiso con la causa aprista, e incluso reporteando a algunos de ellos en sus páginas. En una extensa nota de noviembre de 1931 que llevaba por título «Traviesos pregoneros, los canillitas son los altos parlantes de nuestra difusión», y por subtítulo «Cientos de pequeños compañeros contribuyen con su esfuerzo a nuestra obra de propaganda», podía leerse:

Nuestro diario debe su creciente popularidad, además del que su propio contenido justifica, al voceo que en calles, plazas y lugares de reunión le dan los canillitas. Los canillitas son parte integrante de un diario y constituyen entre nosotros, como en todas las ciudades, el factor indispensable para su difusión. [...] ¡LA TRIBUNA, LA TRIBUNA! El nombre de nuestro periódico se oye incesantemente por toda la ciudad [...]. Los compañeros canillitas [...] van por las calles, penetran a los bares, cafés, clubs. Su voceo constante se oye hasta la noche. ${ }^{50}$

Como parte de los sectores postergados, los canillitas eran uno de los muchos grupos sociales particulares que La Tribuna buscaba atraer a las filas partidarias. Prolongando el sesgo obrerista que había informado desde su inicio la trayectoria política de Haya de la Torre y de las Universidades Populares, uno de los esfuerzos principales del discurso del diario estuvo dirigido a interpelar tanto genéricamente como en sus diferentes segmentos a las clases trabajadoras. Desde su origen, sus páginas se poblaron de titulares y artículos que tanto traían informaciones relativas a esos sectores como buscaban movilizarlos. "Continúa sin solución el conflicto de panaderos», rezaba el título de una nota que se acompańaba de una foto de «los compańeros panaderos»; «Reclaman su derecho a opinar los maestros», se leía en la portada de otra edición..$^{51}$ Pronto el diario se anexó una sección fija — a cargo de los dirigentes obreros Arturo Sabroso y Luis López Aliaga- que llevaba por denominación «La voz de los trabajadores», y que recogía un mosaico de

${ }^{50}$ LT. Núm. 195, 14 de noviembre de 1931, pp. 4-5. Me he ocupado con mayor extensión del asunto de los canillitas en Bergel 2015.

51 LT. Núm. 7, 21 de mayo de 1931, p. 4; y LT. Núm. 18, 1 de junio de 1931, p. 1. 
expresiones y noticias vinculadas al mundo laboral. También las mujeres recibían atención diferenciada, y eran instadas a organizarse en torno a cuestiones específicas. ${ }^{52}$ Como ocurría con los grupos que se constituían a nivel territorial, La Tribuna se posicionó como un dispositivo que a menudo comunicaba sin intermediaciones las demandas y los ensayos organizativos de estratos particulares de trabajadores. ${ }^{53}$

Con arreglo a la pretensión inicial del APRA de conformarse como vehículo del «Frente único de trabajadores manuales y trabajadores intelectuales» — tal era el horizonte de composición sobre el que Haya y sus jóvenes compañeros habían insistido desde sus años de destierro-, el periódico aprista buscó interpelar también a franjas de las capas medias. Sus páginas podían incluir así peticiones de empleados públicos o llamados del «Sindicato aprista de abogados». ${ }^{54}$ En ocasiones, y siguiendo aquí también las directrices impulsadas en los años del exilio por Haya, La Tribuna era portador de un discurso que aludía explícitamente a las «clases medias». ${ }^{55}$ Pero otras veces esa noción aparecía diluida en la más genérica referencia a las "clases productoras», que comprendían una lista que podía incluir a «obreros, empleados, campesinos, estudiantes». ${ }^{66} \mathrm{De}$ conjunto, y contrariando las visiones que han adjudicado al APRA ya en

52 Véase, por ejemplo, la nota «La Sección Femenina del Partido Aprista actúa en forma entusiasta». LT. Núm. 58, 11 de julio de 1931, p. 4.

53 Por caso, véase la nota escrita y firmada por un trabajador individual que apareció bajo el título «La voz de un artesano». LT. Núm. 21, 4 de junio de 1931, p. 8.

54 «Formula un reclamo un empleado». LT. Núm. 147, 6 de octubre de 1931, p. 5; y «Sindicato de abogados apristas». LT. Núm. 275, 30 de enero de 1932, p. 1.

${ }^{55}$ En uno de los recuadros que desde las portadas del diario solían presentar en forma destacada consignas que orientaban la labor del partido, se leía: «Los trabajadores manuales e intelectuales, las clases medias, la pequeńa industria, no serán explotadas» (LT. Núm. 15, 29 de mayo de 1931, p. 1). La frase preside recuadros de otras varias ediciones.

${ }^{56}$ Recuadro de portada de LT. Núm. 120, 10 de septiembre de 1931, p. 1. Esa tesitura del periódico se vinculaba tácitamente a la formulación original de Haya relativa al lugar de las clases medias dentro del "partido de Frente único" que se quería el APRA. La inclusión de esos sectores dentro del aprismo se fundaba en el hecho de que pertenecían también, junto con los obreros y campesinos, a las clases productoras explotadas por el imperialismo. Véase Haya de la Torre 1927. 
sus años primigenios un carácter "pequeño burgués» o dominado por las clases medias, la tónica principal de las apelaciones de La Tribuna orbitaba en torno a un discurso en el que continuaba siendo clave la condición trabajadora (sea asociada al "proletariado» — término detectable con frecuencia en las páginas del diario-, sea para referir a los grupos abarcados por la categoría de «trabajo intelectual»). ${ }^{57}$

Frente a esa matriz clasista que resultaba predominante en la retórica del periódico, las apelaciones al mundo indígena fueron en cambio mucho más espaciadas. En un texto de comienzos de la década de 1970, Thomas Davies se propuso mostrar cómo el indigenismo aprista de los años treinta fue mucho más episódico y menos radical de lo que habitualmente se creía. ${ }^{58} \mathrm{Su}$ perspectiva ayuda a entender por qué la implantación del APRA fue considerablemente más débil en la sierra centro y sur que en el «sólido norte» del país, aun cuando algunos trabajos recientes permiten relativizar esas conclusiones. ${ }^{59}$ Sea como fuere, en su estudio Davies no ponderaba la presencia de la temática indígena en el principal vocero público del APRA del periodo, es decir, La Tribuna. Pues bien, un examen de sus páginas permite corroborar que, en la puesta en práctica de mecanismos de interpelación popular a la que se entregó resueltamente desde su creación en mayo de 1931, el diario aprista apenas si apeló a dimensiones étnico-raciales. Mientras

${ }^{57}$ La fusión en su seno del trabajo manual y el trabajo intelectual era en rigor uno de los mitos de origen del APRA, que en 1931 se revivía a través del recuerdo permanente de la experiencia de la Universidad Popular y de las jornadas de mayo de 1923 contra el gobierno de Leguía (que en la narrativa aprista habían sellado con la sangre de un estudiante y un obrero muertos en las manifestaciones esa alianza constitutiva y fundacional). La condición trabajadora como fundamento de esa amalgama era aludida una vez más en el título de la nota con la que la revista $A P R A$ anunciaba los actos de rememoración de esas jornadas: "Conmemoramos la fecha simbólica de la Unión de las Clases Productoras» (APRA. Segunda Época. Núm. 14, 23 de mayo de 1931, p. 2). Véase también "Hace 8 años que la masacre unificó a obreros y estudiantes». $L T$. Núm. 9, 23 de mayo de 1931, p. 1.

58 Davies 1971.

59 Jaymie Heilman ha mostrado como el APRA, movilizando motivos descentralistas, antioligárquicos e indigenistas, tuvo en los años treinta una significativa presencia en el departamento de Ayacucho, incluso en sus distritos rurales (Heilman 2006). 
«La voz de los trabajadores» fue una sección casi diaria, que se acompañaba además de muchas otras coberturas relativas al mundo laboral, las notas de impronta indigenista aparecieron apenas salpicadamente. ${ }^{60}$ Es dable pensar que esa presencia sensiblemente menor obedeció a motivos pragmáticos: dado su carácter mayoritariamente iletrado, las poblaciones campesinas e indígenas no estarían entre los destinatarios principales del órgano aprista. Pero también es posible conjeturar que, desde un ángulo particular, en cierto sentido La Tribuna participaba también de la estructura ideológica que Paulo Drinot llamó «la seducción de la clase obrera», esto es, la idea según la cual le correspondería a los trabajadores ser el agente principal de modernización del Perú. ${ }^{61}$

Pero en coexistencia y superposición a ese prisma a la vez clasista (por subrayar la condición trabajadora de los grupos a los que interpelaba) y policlasista (puesto que desde ese ángulo convocaba también a los sectores medios), en el discurso del diario se fue afirmando una categoría que abarcaba a todos los estratos que el APRA pretendía representar y que sí constituía una innovación —al menos en cuanto al progresivo protagonismo que adquirió - en relación con las posiciones de los líderes apristas previas a la caída de Leguía: la de pueblo. «Nadie como Haya de la Torre [...] personifica los verdaderos anhelos de mejoramiento del pueblo peruano», se esgrimía en un editorial; «Luchemos por las clases explotadas; es decir, por el pueblo», rezaba el título de una nota enviada por un corresponsal de Cańete; «Llegamos al pueblo porque somos el pueblo mismo", anunciaba otra portada en letra de gran tamańo. ${ }^{62}$ En el camino, en las páginas del diario comenzó a decantarse la idea de que el APRA era quien naturalmente daba expresión a los intereses de las mayorías, una perspectiva que fue sedimentando, hasta afirmarla,

${ }^{60}$ Algunos ejemplos: «Debemos salvar al indio peruano. Vibrante manifiesto de la Secretaría de Asuntos Indígenas del Partido Aprista Peruano». LT. Núm. 7, 21 de mayo de 1931, p. 6; "Contra el gamonalismo de Aimaraes». LT. Núm. 51, 4 de julio de 1931, p. 6; y «Se quejan los indígenas de Huancané». LT. Núm. 114, 4 de septiembre de 1931, p. 6.

${ }^{61}$ Drinot 2016.

${ }^{62}$ LT. Núm. 6, 22 de mayo de 1931, p. 1; LT. Núm. 27, 10 junio de 1931, p. 8; y LT. Núm. 132, 21 de septiembre de 1931, p. 6. 
la propia noción de «Partido del Pueblo». Así, en la crónica de un acto en El Callao a fines de mayo se deslizaba que el líder Carlos Manuel Cox «hizo una reseña de la iniciación aprista, indicando cuales eran las finalidades de este partido del pueblo»; mientras que, ya en septiembre, el periódico recogía un discurso de Haya en el que se afirmaba que «nosotros los apristas debemos sentirnos orgullosos de ser los centinelas de los más sagrados derechos del pueblo [...] nosotros, que somos el partido del pueblo, estamos enseñando orden, organización y línea recta». Dos semanas después, el sintagma era asumido por un obrero en una carta en la que informaba su acoplamiento a las huestes partidarias: "Compañero Manuel Seoane, director de LA TRIBUNA: Hago a usted saber por medio de la presente que en la fecha he hecho renuncia de pertenecer al Club Sánchez Cerro número 1 del Callao; y me he inscrito en las filas del aprismo, por reconocer que éste es el verdadero partido del pueblo». ${ }^{63}$ Meses más tarde, poco antes de ser clausurado por el gobierno de Sánchez Cerro, el órgano aprista mostraba en sus páginas que el apelativo de "Partido del Pueblo» ya se hallaba estabilizado. ${ }^{64}$

La teoría política contemporánea ha insistido en la dimensión relacional inherente a la constitución del pueblo dentro de la praxis discursiva de los movimientos populistas, y en el lugar que tiene el antagonismo político en ese proceso. ${ }^{65}$ La conformación del aprismo como fenómeno de masas tuvo lugar en un cuadro de marcada crispación, y de enconados enfrentamientos retóricos que se continuaron en combates físicos y en un aumento de la violencia política (un escenario que, lejos de apaciguarse luego del triunfo electoral de Sánchez Cerro en octubre de 1931, se exacerbó). En ese sentido, el emplazamiento del «Partido del Pueblo» requirió de la

63 «Rotundo éxito alcanzó el mitin aprista en el Callao. El pueblo chalaco se lanzó a las calles en manifestación». LT. Núm. 15, 29 de mayo de 1931, p. 2; "Haya de la Torre habló ayer ante una manifestación aprista que recorrió el centro». LT. Núm. 114, 4 de septiembre de 1931, p. 1; y «El pueblo consciente no marchará nunca con sus explotadores. Más cartas proletarias». LT. Núm. 127, 17 de septiembre de 1931, p. 6. En las tres citas, el énfasis es mío.

64 «La propaganda cultural del Partido del Pueblo se evidencia más cada día». LT. Núm. 284, 10 de febrero de 1932, p. 5.

${ }^{65}$ Laclau 2005. 
afirmación de una frontera política que sirvió para delimitar un otro contra el cual se irguió el aprismo como identidad popular. Ese campo enemigo con el que se rivalizaba acremente se sintetizaba primero en la categoría de «civilismo» (que remitía al Partido Civil, y que era tradicionalmente utilizada para nominar a la "oligarquía») y luego, ya en 1931, en la de «sanchocivilismo», su versión extendida y adaptada a la nueva situación, en un discurso que tenía diariamente en La Tribuna su principal canal de diseminación. A su vez, esa disputa tenía un correlato estrictamente periodístico, que se expresaba en las diatribas mutuas que se prodigaban el órgano aprista y su adversario por excelencia, El Comercio. ${ }^{66} \mathrm{Y}$ es que, en el marco de esa densa coyuntura política, en espejo a la conformación del APRA como movimiento de masas durante 1931 cristalizó también una sensibilidad política antiaprista. Un eco de ello podía apreciarse ya a fines de mayo en una edición de La Tribuna, que reproducía declaraciones de Haya aún desde Europa en las que se aludía tempranamente al «miedo al aprismo»e incluso a un "terror antiaprista». ${ }^{67}$ En suma, es durante el crucial año sobre el que se concentra este trabajo que se sientan las bases de la inconciliable pugna entre apristas y antiapristas, tan gravitante en las décadas siguientes en el teatro político nacional; y es inicialmente el espacio de la prensa (en retroalimentación con el de la calle) la vía privilegiada de tramitación de ese duelo a la postre histórico.

Y, sin embargo, al mismo tiempo que La Tribuna jugaba un rol de peso en la producción del mencionado antagonismo político, en sus páginas podían leerse posturas que procuraban encauzar y contener las hostilidades. En una tesitura sobre la que se insistiría en numerosos comentarios editoriales, se hacía un llamamiento «a dignificar la política,

${ }^{66}$ Una aproximación a la imagen del APRA en El Comercio a comienzos de los años treinta puede hallarse en Hansen 2010. En uno de los contrapuntos dialógicos en los que se trenzaba con «el decano» del periodismo peruano, mientras salía al cruce del epíteto de "comunista» que se le endilgaba, significativamente La Tribuna asumía, y desde su propia portada, su filiación marxista; véase «Marxismo no es sólo comunismo, Sres. de "El Comercio"». LT. Núm. 283, 7 de febrero de 1932, p. 1.

${ }^{67}$ LT. Núm. 15, 29 de mayo de 1931, pp. 1 y 9. Sobre el «miedo al APRA» como sensibilidad política, véase Klaiber 2005. 
a discutir ideas, abandonar el terreno de la calumnia, del insulto procaz, del dicterio [...] únicas armas del sanchocivilismo». ${ }^{68}$ Surgido como parte de un movimiento generacional que no solo en el Perú se había propuesto regenerar de raíz la política y la cultura americanas, hacia 1931 el APRA se quería superior a sus rivales por sus más elevados móviles y por sus métodos renovadores. En ese marco, en la apuesta de sus dirigentes $L a$ Tribuna debía ser un órgano destinado no solamente a captar el favor de las masas, sino también a educarlas:

Hasta ayer política fue corrupción, compadrería, matonismo, ignorancia audaz, robo, pisco y butifarra [...] por eso, cuando cayeron Leguía y Sánchez Cerro, se perfilaron dos corrientes. La vieja politiquería, con todas sus taras, y la nueva política, con todas sus aspiraciones. Sánchez Cerro personifica el tipo primitivo del hombre que confunde el país con un cuartel. Haya de la Torre simboliza las aspiraciones de una generación que quiere hacer del Perú una escuela. Una escuela donde todos aprendamos y donde reine la justicia [...] Por eso el aprismo es, ante todo, una escuela de civismo. ${ }^{69}$

Algunas facetas de esa cruzada cívica se acentuarían luego de 1932, cuando en el contexto de la «Gran Clandestinidad» el APRA refuerza los rasgos moralizantes, martirológicos y hasta religiosos del discurso que orientaba su praxis. En cambio, en el fragor de las luchas del periodo, el componente regeneracionista de la política y las ideas, que remitía a los tiempos primigenios de las Universidades Populares, se evaporó progresivamente.

Digamos por último que, aunque en los combates del ańo 1931 el APRA y los seguidores de Sánchez Cerro, así como La Tribuna y El Comercio, tendieron a oponerse frontalmente, en algunos aspectos se hallaron disputando los mismos objetos y motivos. Tal es lo que ocurrió ejemplarmente con el tema de la nación, el otro componente que asumió notable centralidad en el discurso aprista. El que se creara desde el exilio como movimiento internacional americano, y predicara en el último de los cinco puntos de su programa inicial de 1926 la «solidaridad con todos

${ }^{68}$ «El civilismo calla ante sus delitos». LT. Núm. 118, 8 de septiembre de 1931, p. 1.

${ }^{69}$ Seoane $1931 \mathrm{~b}$. 
los pueblos y clases oprimidas del mundo», postulaba ahora encarnar «el verdadero nacionalismo», a despecho del que reclamaban defender sus adversarios. Los apristas, se leía en La Tribuna, «somos nacionalistas. Creemos que hay que luchar contra los que hablan de patriotismo pero practican la traición». ${ }^{70}$ En síntesis, fue en las páginas del diario dirigido por Manuel Seoane que, en la coyuntura de inicios de los años treinta, cobró vigor en el APRA la retórica de lo nacional-popular.

\section{UN DIARIO MODERNO}

Pero el éxito de La Tribuna no se debió meramente a las modalidades a través de las cuales sintonizó con el clima de efervescencia partidaria. El retrato de este diario que aquí buscamos ofrecer se vería incompleto si, como ha ocurrido con frecuencia, nos limitáramos a encuadrarlo dentro del espectro de la prensa política. Si su línea editorial y su composición general no ofrecían dudas acerca de su relación orgánica con el APRA, La Tribuna al mismo tiempo se inscribió como un medio gráfico reconocible de pleno derecho dentro del campo periodístico, con cuyos integrantes se propuso competir con arreglo a las legalidades propias de ese espacio. El periódico, decía la nota que ya hemos citado de la revista $A P R A$ que anunciaba su próxima aparición, sería «diario de doctrina», pero también «diario de información». ${ }^{71}$ "Pretendimos que fuera un diario lo más objetivo posible», rememoraría Sánchez a su turno. ${ }^{72}$ Un despacho de la embajada norteamericana al Departamento de Estado desde Lima indicaba también que «La Tribuna [...] ha estado intensificando su propaganda política al mismo tiempo que dedica más espacio a las noticias generales». ${ }^{73}$

70 «El verdadero nacionalismo aprista». LT. Núm. 120, 10 de septiembre de 1931, pp. 1-2. Se debió a Manuel Seoane una de las primeras formulaciones nítidas de esa disputa efectuadas desde las filas del APRA; véase Seoane 1926.

71 «Nuestro diario: a los sordos y a los zurdos», $A P R A$, Segunda Época, núm. 5, 26 de marzo de 1931, p. 2

72 Sánchez 1987b: 12.

${ }^{73}$ Despacho de la embajada norteamericana al Departamento de Estado, Lima, 7 de octubre de 1931, Archivo NARA, Carpeta 5694, Washington DC; traducción mía. 
Digamos entonces que, en coexistencia con las formas de interpelación político-partidarias que marcaban el pulso de sus páginas, el diario aprista desarrolló estrategias de captación de un público educado ya en el hábito de leer periódicos. En adición a sus mecanismos de movilización de afectos modelados en clave de identificaciones políticas y de construcción de referencias de amistad y de enemistad, La Tribuna procuró despertar un plus de interés en aquellos que primordialmente buscaban en el diario satisfacer su curiosidad informativa o hallar materiales vinculados al ocio y al entretenimiento. Para ese cometido, el diario siguió una mecánica ya largamente establecida en los medios gráficos modernos: la de poner a disposición de sus lectores secciones fijas, instancias que suponían diferentes pactos de lectura con diversos segmentos de público. Pero aún en sus variaciones, esa serie apuntaba a un objetivo común: el de potenciar la penetración popular del órgano oficial aprista.

De todas esas secciones, la que ocupó un lugar insustituible en la economía informativa de La Tribuna fue la de deportes. Y ello no solamente porque hacia 1931 todo diario de pretensiones debía proveer noticias relativas al boxeo o al fútbol. Los dirigentes apristas que lideraban el diario, además, tenían predilección por las actividades físicas, tanto en un papel de espectadores como de ejercitadores. Los deportes habían sido un ingrediente importante en la sociabilidad juvenil limeña de figuras como Seoane, Sánchez y el mismo Haya. ${ }^{74}$ Luego, habían tenido un lugar de peso en el diálogo epistolar mantenido por los dos primeros en los ańos veinte. Aún más, para ambos las actividades deportivas fueron materia principal en sus primeras incursiones en el periodismo. Entre 1922 y 1924 Sánchez se involucró en Aire Libre, una revista dedicada exclusivamente a los sports; Seoane, por su parte, desde su exilio en Buenos Aires enviaría colaboraciones recurrentes sobre la temática a distintos medios gráficos peruanos. El hechizo que los deportes producían en amplias franjas populares mereció incluso su mirada reflexiva. En un artículo titulado «La emoción deportiva» publicado en el Boletín Titikaka — la revista de la vanguardia literaria puneña-, escribía:

${ }^{74}$ Chang Rodríguez 2003: 22; y Sánchez 1987a: 176. 
La emoción deportiva agita al mundo contemporáneo, invade el interés ciudadano en proporción absorbente, monopoliza la vida individual de millares de individuos, obsesiona a las masas. ¿Es posible cruzarse de brazos, negarle importancia, pretender substraerse este fenómeno a la órbita de aquellos dignos del estudio y la interpretación? ¿Acaso no se advierte en la emoción deportiva un signo de la época, un reflejo natural y lógico de los lineamientos de la sociedad actual y el fulgor más vivaz del estado de la conciencia humana? ${ }^{75}$

Por todo ello, no es de extrañar que La Tribuna haya dedicado un espacio fijo a los asuntos deportivos. Desde sus primeros números, una, dos y hasta tres páginas de las doce que usualmente componían sus ediciones se dedicaban al boxeo, al fútbol, al atletismo o al ajedrez. Desde su inicio, además, el vocero aprista se propuso fomentar la realización de actividad física en sus lectores, ofreciendo publicar «informaciones, citaciones y otros datos que los clubs de instituciones deportivas envíen a este diario». ${ }^{76} \mathrm{Y}$ es que la ejercitación del cuerpo era otro de los expedientes mentados por el aprismo a la hora de postular su superioridad respecto de sus contrincantes. Según se argumentaba en un artículo titulado "El deporte y el APRA», el propio vigor físico y la juventud que exhibían sus principales referentes en sus campañas proselitistas, empezando por la lozanía y el entusiasmo desbordante de los que hacía gala su líder máximo, obedecían a los beneficios obtenidos de la ejecución de actividades físicas. «Por esto — se afirmaba allí-, el aprismo propugna la necesidad de acudir a los campos deportivos para formar hombres en el amplio sentido de la palabra». ${ }^{77}$

Pero no era esa faceta, que establecía los beneficios integrales que se derivaban del cultivo de actividades físicas para la construcción de una nueva moral partidaria (un precepto por lo demás deudor de la cultura obrera y estudiantil que había informado la experiencia de las Universidades Populares desde comienzos de los años veinte), la que ofrecía el ángulo principal desde el que estaban enfocados los deportes en el diario aprista. En La Tribuna, la sección había nacido haciendo suyos

\footnotetext{
75 Seoane 1929.

76 "Atienda a su club». LT. Núm. 2, 17 de mayo de 1931, p. 2.

77 «El deporte y el APRA». LT. Núm. 93, 15 de agosto de 1931, p. 12.
} 
los lenguajes y técnicas periodísticas habituales en la prensa moderna del siglo XX, que partían de situar al hecho deportivo como espectáculo y a los lectores como gozosos consumidores del conjunto de minucias que lo rodeaban. Coberturas y crónicas de eventos acontecidos, anuncios de otros por venir, informaciones y recuadros estadísticos de una variada gama de disciplinas, etc., formaban parte corriente del menú que poblaba las páginas deportivas del diario. Entre esos géneros, había también un lugar para la entrevista a figuras destacadas del panorama peruano. Una edición se solazaba de publicar «algunas declaraciones que juzgamos de interés para los aficionados» del boxeador Eduardo Carrasco, en un reportaje que se acompańaba de una foto en la que el pugilista aparecía leyendo atentamente un ejemplar del periódico. ${ }^{78}$

Junto con la proliferación de los deportes, las sociedades urbanas latinoamericanas de las primeras décadas del siglo XX asistieron a la expansión de una trama de actividades vinculadas al ocio y a los espectáculos artísticos. Siguiendo ese movimiento y al desarrollado por una prensa que había sido actor decisivo en ese proceso, La Tribuna prohijó también en sus páginas un espacio permanente dedicado al cine, el teatro y otros quehaceres lindantes. Partiendo de asumir el magnetismo que las industrias culturales ejercían sobre las clases medias y populares (según se leía en una nota, "para la vida del país [...] [el] cinema tiene mayor importancia que la cuestión electoral y que el problema de la desocupación»), ${ }^{79}$ el periódico se ofreció desde sus comienzos como canal de divulgación de la oferta artística limeńa, proveyendo cotidianamente informaciones sobre las producciones que se exhibían en la capital y sobre los elencos extranjeros que la visitaban. También en este rubro el órgano aprista incorporó la lógica de las celebrities típica de la prensa de masas, en función de extraer provecho del embelesamiento que generaban las figuras del espectáculo. Por caso, en una serie de apostillas vinculadas al mundo teatral, el diario podía consignar referencias como la siguiente:

\footnotetext{
78 «Quiero dejar demostrado que soy superior al campeón ecuatoriano, nos dijo ayer Eduardo Carrasco». LT. Núm. 21, 4 de junio de 1931, p. 12.

79 «La terrible cuestión de los pases de cinema». LT. Núm. 3, 18 de mayo de 1931, p. 8.
} 
Ayer hemos recibido la visita de la simpática vedette argentina, señorita Ibis, quien vino a manifestarnos que los rumores acerca de su presunto matrimonio son absolutamente falsos. Afirma la señorita Ibis que no ha abdicado de su soltería y que, por consiguiente, proseguirá su feliz campaña teatral. ${ }^{80}$

Más episódico resultó ser en La Tribuna un segmento que también se había granjeado desde décadas atrás un lugar visible en las páginas de los periódicos masivos: el que daba cuenta de los asuntos policiales. Para los órganos de prensa que aspiraban a conquistar un público popular, las historias del mundo del delito constituían un recurso inestimable a la hora de aguijonear la atención de los lectores. El diario aprista no quiso ser menos que sus pares ya establecidos, y así cobijó en su interior un tipo de noticia breve agrupada en series bajo títulos reconocibles como «Hechos de Policía» o «Calaboceando». La sección tuvo presencia en el diario ya en su segundo número, lo que delata el carácter programático que su inclusión tenía dentro de su apuesta periodística. ${ }^{81}$ No obstante, en comparación con lo que acontecía en otros periódicos de la época, el espacio consagrado a esta temática tuvo un desarrollo limitado en $\mathrm{La}$ Tribuna, que se inhibió de merodear los tonos altisonantes y los detalles escabrosos que podían advertirse en otros medios. Seoane había sido testigo de primera mano, durante su exilio argentino, de la favorable suerte corrida por un órgano de prensa que ejercía esa tendencia hasta el paroxismo: nada menos que Crítica, que basaba parte de su fenomenal éxito de público en el cultivo de un estilo marcadamente sensacionalista, y cuyas coberturas de los casos policiales no escatimaban ni las tomas abiertas de posición (a menudo en favor de figuras provenientes del hampa) ni las impudorosas inspecciones de las facetas curiosas o truculentas que rodeaban los hechos delictivos. ${ }^{82} \mathrm{Y}$ aun así, en su afán no solo por capturar sino también por educar a las clases subalternas, La Tribuna no cedió al ejercicio de un periodismo de ese carácter. Y si no dejó de

\footnotetext{
80 "Teatros». LT. Núm. 41, 24 de junio de 1931, p. 4.

81 «Hechos de policía». LT. Núm. 2, 17 de mayo de 1931, p. 11.

${ }^{82}$ Sobre el sensacionalismo de Crítica en el tratamiento de los sucesos policiales, véase el notable ensayo de Caimari 2003.
} 
visitar esa parcela de la actualidad que abonaba los corrillos noticiosos de las grandes metrópolis, le otorgó en sus páginas un lugar acotado.

Conforme se aproximaban las elecciones de octubre de 1931, la lucha política entre apristas y sanchezcerristas se intensificó, y con ello el sesgo partidario de La Tribuna. Y sin embargo, y aunque pasados los comicios la conflictividad, lejos de apaciguarse, se incrementó, hacia noviembre el diario se dio a la tarea de ampliar y renovar su menú periodístico. En una edición de ese momento se anunciaba lo siguiente:

Con el fin de atender debidamente el creciente favor que nos dispensan nuestros lectores, hemos resuelto introducir, de acuerdo con la índole de nuestro diario, algunas mejoras en su servicio. En adelante nuestra edición corriente tendrá, aparte de la información política, amplia e interesante información de carácter general. Con tal objeto hemos adquirido, también, un servicio noticioso especial de la United Press, que nos permitirá dar a conocer a nuestros lectores los hechos ocurridos en el exterior. ${ }^{83}$

Medio año después de su aparición, y cuando orillaba los 25 mil ejemplares editados cada día, el vocero aprista incorporaba otra zona noticiosa impostergable para todo diario con aspiraciones: el de los cables del exterior, que disponían un canal inmediato de información de los eventos que tenían lugar en todo el globo. Según otra postal retrospectiva de Sánchez, la escasez de recursos con la que La Tribuna comenzó su derrotero había tornado inviable la contratación desde sus inicios del oneroso servicio provisto por las agencias de noticias internacionales. ${ }^{84}$ Ahora, ya consolidado, el periódico no demoraba en afiliarse a una de esas empresas, y comenzaba a ofrecer una sección que había sido desde fines de siglo XIX un eslabón clave en la modernización de la prensa.

El mismo recuadro, además, informaba que «en nuestras ediciones dominicales ofreceremos interesantes colaboraciones de distinguidos escritores nacionales y extranjeros, exclusivos para nuestro diariom. ${ }^{85}$

83 “"La Tribuna” mejora sus servicios correspondiendo el favor que el público le dispensa». LT. Núm. 193, 12 de noviembre de 1931, p. 12.

${ }^{84}$ Sánchez 1978.

85 “"La Tribuna” mejora sus servicios correspondiendo el favor que el público le dispensa». LT. Núm. 193, 12 de noviembre de 1931, p. 12. 
Con ello el vocero del aprismo buscaba oficializar un tipo de espacio que también era moneda corriente en los grandes periódicos del continente: su página semanal literaria. Un apartado de esta índole no era difícil de concebir para quienes comandaban La Tribuna, que además de referentes políticos y diestros periodistas eran reconocidos por sus disposiciones intelectuales. Así, ya la primera entrega de la sección incluía una evocación de Sánchez de la ciudad de Valparaíso, un encendido elogio de Seoane de la rebeldía juvenil, y una semblanza del escritor norteamericano Waldo Frank, además de un poema de Serafín Delmar. ${ }^{86}$

En suma, si desde sus primeros pasos La Tribuna se inscribió como una experiencia que se propuso cortejar distintas parcelas de público a la vez que ofrecer disputa dentro del dinámico campo del periodismo escrito en el Perú, hacia fines de 1931 había completado ya aventajadamente la anexión del conjunto de flexiones usuales en los más caracterizados exponentes de la prensa periódica del continente. Los avatares de la política, que explicaban buena parte de su vertiginoso ascenso, pondrían sin embargo coto a ese curso venturoso. La elección de Seoane y Sánchez al Congreso Constituyente que comenzó a funcionar en diciembre los alejó parcialmente del diario, cuya dirección recaló en Manuel Solano. Pero fue sobre todo la feroz represión sobre el aprismo desatada desde el Estado por Sánchez Cerro en los albores de 1932 la que sellaría la suerte de esta etapa inicial de La Tribuna, que en febrero de ese año era clausurada.

\section{A MODO DE CIERRE}

En este artículo hemos ensayado una aproximación a un objeto que hasta aquí no había sido examinado en profundidad en los abordajes del problema del veloz crecimiento que experimentó el APRA a comienzos de los ańos treinta: el diario partidario La Tribuna. Como hemos tratado de mostrar, este periódico fue un artefacto crucial en la construcción de un "pueblo aprista», a través de dos estrategias combinadas: por un lado, a partir de constituirse en eje vertebrador de la vida partidaria, en

${ }^{86}$ LT. Núm. 196, 15 de noviembre de 1931, pp. 4-5. 
un marco en que periódico, lectura y presencia de la militancia callejera - incentivada por la coyuntura electoral de octubre de 1931 - se reenviaban mutuamente; por otro, al desarrollar con pericia periodística (adquirida por quienes lideraban el diario tanto en el exilio argentino como en el propio escenario de modernización de la prensa en el Perú) una economía informativa que se desplegaba en un conjunto de secciones y formatos que coadyuvaron a captar la atención del público lector de periódicos.

Uno de los problemas habituales en la historiografía sobre el APRA es el de proyectar indiferenciadamente sobre su pasado rasgos que solo adquirieron preeminencia posteriormente. Este déficit de periodización conlleva un aplastamiento del tiempo histórico y una desconsideración de los cambios y matices que fue adquiriendo el movimiento con arreglo a los distintos contextos en los que le tocó actuar. El aprismo fue además un fenómeno que congregó en su seno una multitud de actores heterogéneos, y que por ende no se deja aprehender bajo fórmulas simplificadoras. En el caso de los atributos que permiten encuadrarlo dentro de la familia de los populismos latinoamericanos clásicos, ellos comienzan a perfilarse con alguna nitidez solo a partir de 1931. Si bien algunas formulaciones doctrinarias y ciertos condimentos de la matriz emocional que distinguiría la cultura política del APRA pueden detectarse ya en los años veinte, por entonces no pasaba de ser una red desterritorializada de pequeños núcleos y personas que, sin dejar de vincularse con la realidad peruana, pretendía liderar un movimiento internacional a escala continental. El escenario cambiaría radicalmente con la caída de Leguía y con el posterior llamado a elecciones presidenciales para fines de 1931. Es en el vértigo de ese proceso que el aprismo se transforma en un hecho de masas, con presencia en la totalidad del territorio peruano (cierto que con consabidos grados diversos de implantación según las regiones). En ese marco, La Tribuna jugaría un papel de relieve como organizador y propagador de la vida partidaria, y como dispositivo que generaliza la noción de que el APRA es el movimiento que encarna por excelencia los intereses del pueblo. Pero como hemos querido señalar en este texto, el discurso nacional-popular tan caro a los fenómenos populistas convive 
en las páginas del diario con otro en el que las clases trabajadoras siguen siendo objeto privilegiado de interpelación (al tiempo que, en otro plano, las proclamaciones ocasionales de una identidad marxista podían coexistir con una postura que manifestaba creciente permisividad hacia el capital extranjero). ${ }^{87}$ En definitiva, contra la pretensión de extraer de sus páginas posicionamientos ideológicos "puros», en el trajín de su primer año de existencia La Tribuna prohijó una combinación de elementos populistas y socialistas. Y fue solo conforme avanzó la década de 1930 que los primeros obtendrían paulatina primacía sobre los segundos, en un derrotero poco perceptible dadas las condiciones de clandestinidad en las que el movimiento debió desenvolverse.

Junto con ese rol articulador de la dinámica partidaria, según hemos abundado aquí el vocero del APRA reforzó su ascendencia sobre su público al desplegar formatos periodísticos que lo colocaban en sintonía con lo más avanzado de la prensa moderna. Ese desarrollo de secciones no supuso - en comparación con las modalidades empleadas por otros diarios como El Comercio - un diferente tipo de abordaje de áreas informativas como los deportes o los casos policiales. En este sentido, en el caso del periódico aprista no se verifica la sugerente pero discutida hipótesis esgrimida por Matthew Karush en su análisis del diario Crítica de la década de 1920. Según este historiador, el medio gráfico argentino llevó a cabo un tratamiento "populista» de los deportes, que colaboró en la construcción de una cultura antagónica a los sectores dominantes (cuyas señas de identidad se veían reflejadas en periódicos de otra prosapia, como La Nación). ${ }^{88}$ Conforme hemos podido ver anteriormente, tampoco La Tribuna participó del sesgo sensacionalista con que otros medios (y en especial nuevamente Crítica) enfocaban los casos policiales. A este respecto, corresponde decir que el periódico mantenía en 1931 cierta impronta ilustrada (en el sentido de una vocación por educar a los sectores populares) propia de la cultura de izquierda anarquista y

${ }^{87}$ Véase, por ejemplo, el editorial «Aprismo y capitalismo». LT. Núm. 121, 11 de septiembre de 1931, p. 1.

${ }^{88}$ Karush 2003. 
socialista en la que el APRA se había formado, ${ }^{89}$ y que sus ansias por ubicarse como vocero de las mayorías populares no redundaron en un estilo periodístico que podamos llamar "populista». ${ }^{90}$ En síntesis, si el diario aprista fue un instrumento que intervino en la lucha política y en la constitución de un "pueblo aprista» en el Perú de inicios de los años treinta, ello fue por el modo en que sus distintos posicionamientos y sus modos de interpelación compusieron una trama distintiva, y no por algún tipo de tramitación singular de sus secciones periodísticas. Por el contrario, hemos querido argumentar que el éxito de La Tribuna obedeció en parte al modo en que en el cuerpo del diario se replicaron mecanismos de probada eficacia en la prensa moderna del periodo, tanto en el Perú como en otros países del continente.

Digamos por último que la encarnizada persecución que el gobierno de Sánchez Cerro emprendió contra el APRA tras su triunfo electoral, terminó reconfigurando por completo las funciones y la fisonomía del periódico partidario. Clausurado en febrero de 1932, reaparecería a las pocas semanas en un formato marcadamente distinto, sin las secciones que lo habían caracterizado, en condiciones rigurosamente clandestinas, y con una periodicidad por demás irregular (editado incluso a veces desde el exilio). Despojado de su aspecto de diario moderno, pero instalado ya como uno de los más importantes emblemas apristas, el periódico, ahora apenas un boletín de pocas páginas cargado en su propio nombre y en su circulación material de un aura de resistencia, continuaría bajo esos nuevos ropajes jugando un rol clave en la economía sentimental del APRA como movimiento popular. ${ }^{91}$

${ }^{89}$ Una impronta que, en cuanto a ese afán por ilustrar de los estratos trabajadores de avanzada, hundía sus raíces en el siglo XIX; véase García-Bryce 2004.

${ }^{90}$ Esa matriz ilustrada se observa en la insistencia con la que desde los editoriales del diario se buscaba presentar al APRA como un movimiento orientado por ideas. En una ocasión se leía: «El aprismo ha surgido para constituir un partido de ideas y no un clan de compadritos. Nos interesa difundir en la conciencia del pueblo peruano el conocimiento de sus problemas e indicar las soluciones científicas que corresponden» («Métodos reveladores». LT. Núm. 71, 23 de julio de 1931, p. 1).

91 Esbozo esta vía de análisis, sobre la que me encuentro trabajando en la actualidad, en Bergel 2013b. 


\section{BIBLIOGRAFÍA}

Aguirre, Carlos. 2014. "Hombres y rejas. El APRA en prisión, 1932-1945». Bulletin de l'Institut Francais d'Etudes Andines. Vol. 43, núm. 1: 7-30. https:// doi.org/10.4000/bifea.4234

Alegría, Ciro. 1978. Mucha suerte con harto palo. Memorias. Lima: Ediciones Varona. Bergel, Martín. 2007. «Manuel Seoane y Luis Heysen: el entrelugar de los exiliados apristas peruanos en la Argentina de los veintes». Políticas de la Memoria. Núm. 6/7: 124-143.

. 2009. «Nomadismo proselitista y revolución. Notas para una caracterización del primer exilio aprista (1923-1931)». Estudios Interdisciplinarios de América Latina y el Caribe. Vol. 20, núm. 2: 41-66.

. 2010. «La desmesura revolucionaria. Prácticas intelectuales y cultura vitalista en los orígenes del aprismo peruano (1921-1930)». En Altamirano, Carlos (dir.), Historia de los Intelectuales en América Latina. Vol. 2. Los avatares de la «ciudad letrada» en el siglo XX. Buenos Aires: Katz, 301-324.

. 2013a. "Los "intelectuales menores" en la génesis del Partido Aprista Peruano. Algunas consideraciones iniciales». Prismas. Revista de Historia Intelectual. Núm. 17: 184-189.

. 2013b. «Populismo y cultura impresa. La clandestinidad literaria en la formación del Partido Aprista Peruano (1930-1945)». Ipotesi. Revista de Estudos Literarios. Vol. 17, núm. 2: 135-146.

. 2014. «Un partido hecho de cartas. Exilio, redes diaspóricas, y el rol de la correspondencia en la formación del aprismo peruano (1921-1931)». Políticas de la Memoria. Núm. 15: 61-75.

. 2015. «De canillitas a militantes. Los niños y la circulación de materiales impresos en el proceso de popularización del Partido Aprista Peruano (19301945)». Iberoamericana. Vol. 15, núm. 60: 131-145.

. 2017. «El Testimonio Personal de Luis Alberto Sánchez. Memorias inevitables de un americano del siglo XX». Políticas de la Memoria. Núm. 17: 66-78.

Burga, Manuel y Alberto Flores Galindo. 1994. Apogeo y crisis de la República Aristocrática. En Flores Galindo, Alberto. Obras Completas, Tomo II. Lima: Sur, 7-364.

Caimari, Lila. 2003. "Crítica, o las extravagancias de la justicia popular». Prismas. Revista de Historia Intelectual. Núm. 7: 139-152.

Cicarelli, Orazio. 1973. Militarism, aprismo and violence in Peru: the presidential elections of 1931. Buffalo: State University of New York at Buffalo.

Chang Rodríguez, Eugenio. 2003. «Introducción». En Manuel Seoane. Páginas escogidas. Lima: Editorial del Congreso del Perú, 21-39.

Davies, Thomas. 1971. «The Indigenismo of the Peruvian Aprista Party: A Reinterpretation». Hispanic American Historical, Review. Vol. 51, núm. 4: 626-645. https://doi.org/10.2307/2512054 
Dorais, Geneviéve. 2014. Indo-America and the Politics of APRA Exile, 1918-1945. Tesis de Doctorado. Madison: University of Wisconsin. 2017. "Coming of Age in Exile: Víctor Raúl Haya de la Torre and the Genesis of the American Popular Revolutionary Alliance (APRA), 1923-1931». Hispanic American Historical Review. Vol. 97, núm. 4: 651-679. https://doi. org/10.1215/00182168-4214322

Drinot, Paulo. 2012. «Creole Anti-Communism: Labor, the Peruvian Communist Party, and APRA, 1930-1934». Hispanic American Historical Review. Vol. 92, núm. 4: 703-736. https://doi.org/10.1215/00182168-1727981

2016. La seducción de la clase obrera. Trabajadores, raza y la formación del Estado peruano. Lima: Instituto de Estudios Peruanos.

Flores Galindo, Alberto. 1996. «Aprismo y clases populares». En Obras Completas, tomo IV. Lima: Sur, 299-305.

García-Bryce, Iñigo. 2004. República con ciudadanos: Los artesanos de Lima, 18211879. Lima: Instituto de Estudios Peruanos.

. 2010. "A Revolution remembered, a Revolution Forgotten. The 1932 Aprista Insurrection in Trujillo, Perú». A Contracorriente. Vol. 7, núm. 10: 277-322. . 2014. "Trasnational Activist: Magda Portal and the American Popular Revolutionary Alliance (APRA), 1926-1950». The Americas. Vol. 70, núm. 4: 667-706. https://doi.org/10.1353/tam.2014.0052

Gargurevich, Juan. 1991. Historia de la prensa peruana, 1594-1990. Lima: La Voz. Giesecke, Margarita. 2010. La insurrección de Trujillo. Lima: Editorial del Congreso del Perú.

Glave, Luis y Jaime Urrutia. 2000. «Radicalismo político en élites regionales: Ayacucho 1930-1956». Debate Agrario. Núm. 31: 1-37.

Gonzales, Osmar. 2006. Federico More. Un maestro del periodismo peruano. Lima: Universidad Alas Peruanas.

Hansen, Sönke. 2010. «Nuevas opciones políticas en el Perú durante la Gran Depresión: la imagen del APRA en El Comercio (1931-1933)». Histórica. Vol. 34, núm. 2: 99-127.

Haya de la Torre, Víctor Raúl. 1927. «Sobre el papel de las clases medias en la lucha por la independencia económica de América Latina». Amauta, núm. 9, mayo, pp. 6-7.

1932. Impresiones de la Rusia soviética y la Inglaterra Imperialista. Buenos Aires: Claridad.

Haya de la Torre, Víctor Raúl y Luis Alberto Sánchez. 1982. Correspondencia. Lima: Mosca Azul, 2 vols.

Heilman, Jaymie. 2006. "We Will No Longer Be Servile: Aprismo in 1930s Ayacucho». Journal of Latin American Studies. Vol. 38, núm. 3: 491-518. https:// doi.org/10.1017/s0022216x06001143 
Karush, Matthew. 2003. «National Identity in the Sports Pages Football and the Mass Media in 1920s Buenos Aires». The Americas. Vol. 60, núm. 1: 11-32. https://doi.org/10.1353/tam.2003.0073

Klaiber, Jeffrey. 1975. "The Popular Universities and the Origins of Aprismo, 1921-1924». Hispanic American Historical Review. Vol. 55, núm. 4: 693-715. https://doi.org/10.2307/2511950

. 1978. «El APRA: religión y legitimidad popular, 1923-1945». Apuntes. Núm. 8: 49-58.

2005. «El miedo al APRA». En Rosas, Claudia (ed.). El miedo en el Perú. Siglos XVI al XX. Lima: Pontificia Universidad Católica del Perú, 257-264.

Klarén, Peter. 1970. Formación de las haciendas azucareras y orígenes del APRA. Lima: Instituto de Estudios Peruanos.

Laclau, Ernesto. 2005. La razón populista. Buenos Aires: Fondo de Cultura Económica.

Landázuri, Javier (ed.). 2015. Los inicios. Lima: Fundación Armando Villanueva del Campo, 2 vols.

Macera, Pablo y Armando Villanueva del Campo. 2011. Arrogante montonero. Conversaciones. Lima: Editorial del Congreso del Perú.

Manrique, Nelson. 2009. «isted fue aprista!». Bases para una historia crítica del APRA. Lima: Pontificia Universidad Católica del Perú.

Melgar Bao, Ricardo. 2018. «El antiimperialismo de la revista Indoamérica: México 1928». Pacarina del Sur. Núm. 34. http://pacarinadelsur.com/home/ mallas/1589-el-antiimperialismo-de-la-revista-indoamerica-mexico-1928

Mendoza Michilot, María. 2013. 100 años de periodismo en el Perú. Tomo 1, 19001948. Lima: Universidad de Lima.

Nugent, David. 1997. Modernity at the Edge of Empire: State, Individual and Nation in Northern Peruvian Andes. Stanford: Stanford University Press.

Planas, Pedro. 1986. Los orígenes del APRA. El joven Haya. Lima: Okura.

Roniger, Luis y Mario Sznajder. 2013. La politica del destierro y el exilio en América Latina. México: Fondo de Cultura Económica.

Sabroso, Arturo. 1961. «"La Tribuna”, matriz del periodismo democrático». La Tribuna, 16 de mayo.

Saítta, Sylvia. 1998. Regueros de tinta. El diario Crítica en la década de 1920. Buenos Aires: Sudamericana.

Sánchez, Luis Alberto. 1961. "Testimonio sobre un periódico combativo y sin fortuna ("La Tribuna" de Lima)». La Tribuna, 16 de mayo. . 1978. «La fundación del "PAP” y "La Tribuna”». Ojo, núm. 3732, 1 de octubre.

. 1987a. Testimonio Personal.1: El Aquelarre 1900-1931. Lima: Mosca Azul. . 1987b. Testimonio Personal. 2: El Purgatorio 1931-1945. Lima: Mosca Azul. 
. 1987c. Testimonio Personal. 5: El descanso del guerrero 1967-1976. Lima: Mosca Azul.

Seoane, Manuel. 1926. "Nacionalismo verdadero y Nacionalismo mentiroso». Amauta. Núm. 4: 19.

. 1929. «La emoción deportiva». Boletín Titikaka, Puno, núm. 29, abril.

. 1931a. «Aniversario argentino». La Tribuna, núm. 11, 25 de mayo, p. 3

. 1931b. «El aprismo como escuela». La Tribuna, núm. 93, 15 de agosto, p. 1

Sessa, Leandro. 2010. «Manuel Seoane ensayista. Una "mirada aprista" de la Argentina de los años treinta». Pacarina del Sur. Núm. 4. http://pacarinadelsur.com/ home/figuras-e-ideas/115-manuel-seoane-ensayista-una-mirada-aprista-de-laargentina-de-los-treinta

. 2014. «El pasado desde el exilio. Las efemérides apristas y la trama del destierro en la Argentina en los años treinta». En Bisso, Andrés; Emmanuel Kahan y Leandro Sessa (eds.), Formas políticas de celebrar y conmemorar el pasado (1930-1943). Buenos Aires: Ceraunia, 60-86.

Solano, Manuel. 1961. "La Tribuna y el aprismo me hicieron periodista». La Tribuna, 16 de mayo.

. 1984. «Manuel Seoane: mi maestro inolvidable». En Manuel Seoane, Izquierda aprista: el verbo vigoroso de Manuel Seoane marca con fuego una posición politica. Lima: Okura, 377-379.

Stein, Steve. 1980. Populism in Peru. The Emergence of the Masses and the Politics of Social Control. Madison: The University of Wisconsin Press.

Taylor, Lewis. 2000. "Los orígenes del Partido Aprista Peruano en Cajamarca, 1928-1935». Debate Agrario. Núm. 31: 39-62.

Townsend Ezcurra, Andrés. 1989. 50 años de aprismo. Memorias, ensayos y discursos de un militante. Lima: Desa.

Vásquez, Emilio. 1931. "Todo el sur es descentralista. Emilio Vásquez, escritor puneño, da su opinión». La Tribuna, núm. 3, 18 de mayo, p. 5.

Vega-Centeno, Imelda. 1991. Aprismo popular. Cultura, religión y política. Lima: Centro de Investigaciones Sociológicas, Económicas, Políticas y Antropológicas. Wallace, Ivonne. 2017. Most Scandalous Woman: Magda Portal and the Dream of Revolution in Peru. Norman: The University of Oklahoma Press.

Fecha de recepción: 3/II/2018 Fecha de aceptación: 21/III/2018 